Open Access

\title{
Do bilateral social security agreements deliver on the portability of pensions and health care benefits? A summary policy paper on four migration corridors between EU and non-EU member states
}

Robert Holzmann(iD

Correspondence:

robert.holzmann@oeaw.ac.at Austrian Academy of Sciences, Vienna, Austria

\begin{abstract}
This policy paper summarizes four corridor studies on bilateral social security agreements (BSSAs) between four European Union (EU) member and two nonmember states, draws conclusions on their results, and offers recommendations. BSSAs between migrant-sending and migrant-receiving countries are seen as the most important instrument to establish portability of social security benefits for internationally mobile workers. Yet, only about $23 \%$ of international migrants profit from BSSAs and their functioning has been little analyzed and even less assessed. The four corridors studied (Austria-Turkey, Germany-Turkey, Belgium-Morocco, and France-Morocco) were selected to allow for comparison of both similarities and differences in experiences. The evaluation of these corridors' BSSAs was undertaken against a methodological framework and three selected criteria: fairness for individuals, fiscal fairness for countries, and bureaucratic effectiveness for countries and migrant workers. The results suggest that the investigated BSSAs work and overall deliver reasonably well on individual fairness. The results on fiscal fairness are clouded by conceptual and empirical gaps. Bureaucratic effectiveness would profit from information and communication technology-based exchanges on both corridors once available.

JEL Classification: D69, H55, 119, J62
\end{abstract}

Keywords: Acquired rights, Labor mobility, Migration corridor, Administration, Evaluation

\section{Introduction}

The share of individuals living outside their home country is increasing again after a temporary low in the 1960s, reaching $3.3 \%$ of the world population in 2015 (up from $2.8 \%$ in 2000), or an estimated 244 million people (United Nations-Department of Economic and Social Affairs 2015). In 2013, non-European Union (EU) citizens residing in EU-28 numbered 20.4 million or $4 \%$ of the EU population; the share of the foreign-born population in 2013 was $7 \%$ and is rising (Eurostat 2015). Overall, the 
world's population seems to be in a new phase of migration movements, soon to match and exceed the migration peaks in mankind's history (Manning 2013; Maunu 2014).

This rising share of individuals living temporarily or permanently abroad broadly reflects three developments: (a) globalization, which besides the expanding trade in goods and services and the movement of capital also increasingly includes the international mobility of labor; (b) population aging, which in the most advanced countries implies a stagnating or even falling domestic population, creating pull/push effects from countries with an exploding young labor force; and (c) military conflicts, terrorism, and environmental degradation, all of which create waves of migrants in search of protection and better lives.

As a result, the migrant stock numbers outlined above-impressive as they may be-underestimate the underlying labor mobility dynamics, that is, the number and increasing share of individuals who have lived or will live at least some part of their working or retired life outside their traditional country of residence. While this development is difficult to quantify due to individuals' multiple migration spells, sometimes to multiple countries, indications from across the world are strong that time spent abroad is increasing. In the EU, the number of citizens who spend at least some of their adult life living outside their home country (as a student, intern, intra-firm and inter-firm mobile employee, labor migrant, or "snowbird" retiree) is definitely rising and may soon be as high as one out of every five individuals. Labor migration pressure toward Europe and labor market needs within Europe have been prevalent for some time and will intensify with population aging. These phenomena are conjectured to be particularly pronounced for the EU's neighboring countries across the Mediterranean and build on migration movements that started as early as the 1960s.

Based on past cross-border labor flows dating back several decades, an indicator of the magnitude and dynamics of pension benefit portability is the number or amount of pension benefits paid abroad as a share of total benefits. Table 1 offers available but not easily accessible information for the investigated labor-receiving countries: Austria, Germany, Belgium, and France. ${ }^{1}$ For the smaller countries, Austria and Belgium, the share of number of benefits paid abroad is around $10 \%$ and rising but not linearly. For the larger countries, France and Germany, the magnitudes are less but are rising markedly for Germany as measured by the number of beneficiaries abroad and rising slowly for France, as measured in benefit expenditure. The French euro value measure underestimates the magnitude compared to that of Belgium as it relates the flows sent abroad from a subset of pension schemes (that is, without civil servants and so on) to the total expenditures of all schemes (no comparable data accessible). The difference in benefit numbers and euro amounts flowing abroad represents the lower benefits for returning migrants, reflecting their shorter contribution period and often lower wage levels.

For internationally mobile workers, two issues are crucial: (a) the access of workers and their families to social security benefits while working abroad and (b) the portability across borders of acquired rights/benefits in disbursement when they move on or retire to a different country of residency. Working foreigners and their families are basically interested in all social benefits and as a starting position of policy analysis, they should face no discrimination in benefit access compared to local workers. This policy perspective may change with regard to temporary migrants, particularly seasonal workers, in as far as their needs' profile differs from that of long-term migrants 
Table 1 Total number or amounts of pensions and those paid abroad: 2004, 2010, and 2014

\begin{tabular}{|c|c|c|c|c|c|c|}
\hline \multicolumn{7}{|l|}{ Austria } \\
\hline \multirow[t]{2}{*}{ Numbers (Dec 31) } & \multicolumn{2}{|l|}{2004} & \multicolumn{2}{|l|}{2010} & \multicolumn{2}{|l|}{2014} \\
\hline & $\begin{array}{l}\text { All } \\
\text { pensions }\end{array}$ & $\begin{array}{l}\text { Old-age } \\
\text { pensions }\end{array}$ & $\begin{array}{l}\text { All } \\
\text { pensions }\end{array}$ & $\begin{array}{l}\text { Old-age } \\
\text { pensions }\end{array}$ & $\begin{array}{l}\text { All } \\
\text { pensions }\end{array}$ & $\begin{array}{l}\text { Old-age } \\
\text { pensions }\end{array}$ \\
\hline Total & $2,041,997$ & $1,114,867$ & $2,219,923$ & $1,494,763$ & $2,310,749$ & $1,615,382$ \\
\hline Paid abroad & 225,662 & 128,396 & 257,062 & 172,212 & 273,035 & 118,484 \\
\hline $\ln \%$ & $11.1 \%$ & $11.5 \%$ & $11.6 \%$ & $11.5 \%$ & $11.8 \%$ & $11.7 \%$ \\
\hline \multicolumn{7}{|l|}{ Germany } \\
\hline \multirow[t]{2}{*}{ Numbers (Dec 31) } & \multicolumn{2}{|l|}{2004} & \multicolumn{2}{|l|}{2009} & \multicolumn{2}{|l|}{2013} \\
\hline & $\begin{array}{l}\text { All } \\
\text { pensions }{ }^{\mathrm{a}}\end{array}$ & $\begin{array}{l}\text { Old-age } \\
\text { pensions }\end{array}$ & $\begin{array}{l}\text { All } \\
\text { pensions }\end{array}$ & $\begin{array}{l}\text { Old-age } \\
\text { pensions }\end{array}$ & $\begin{array}{l}\text { All } \\
\text { pensions }{ }^{\mathrm{a}}\end{array}$ & $\begin{array}{l}\text { Old-age } \\
\text { pensions }\end{array}$ \\
\hline Total & $24,253,612$ & $16,647,948$ & $24,932,492$ & $17,541,732$ & $25,164,401$ & $17,687,735$ \\
\hline Paid abroad & $1,385,244$ & 930,146 & $1,577,562$ & $1,094,328$ & $1,724,688$ & $1,219,670$ \\
\hline $\ln \%$ & $5.7 \%$ & $5.6 \%$ & $6.3 \%$ & $6.2 \%$ & $6.9 \%$ & $6.9 \%$ \\
\hline \multicolumn{7}{|l|}{ Belgium } \\
\hline \multirow[t]{2}{*}{ Numbers (Jan 31) } & \multicolumn{2}{|l|}{2004} & \multicolumn{2}{|l|}{2010} & \multicolumn{2}{|l|}{2014} \\
\hline & $\begin{array}{l}\text { All } \\
\text { pensions }{ }^{a}\end{array}$ & $\begin{array}{l}\text { Old-age } \\
\text { pensions }\end{array}$ & $\begin{array}{l}\text { All } \\
\text { pensions }\end{array}$ & $\begin{array}{l}\text { Old-age } \\
\text { pensions }\end{array}$ & $\begin{array}{l}\text { All } \\
\text { pensions }{ }^{\mathrm{a}}\end{array}$ & $\begin{array}{l}\text { Old-age } \\
\text { pensions }\end{array}$ \\
\hline Total & $1,727,310$ & n. a. & $1,791,526$ & n. a. & $1,938,773$ & n. a. \\
\hline Paid abroad & 164,243 & n. a. & 178,899 & n. a. & 190,477 & n. a. \\
\hline $\ln \%$ & $9.5 \%$ & n. a. & $10.0 \%$ & n. a. & $9.8 \%$ & n. a. \\
\hline $\begin{array}{l}\text { Amount in euro (in } \\
\text { thousands) }\end{array}$ & $\begin{array}{l}\text { All } \\
\text { pensions }{ }^{\mathrm{a}}\end{array}$ & $\begin{array}{l}\text { Old-age } \\
\text { pensions }\end{array}$ & $\begin{array}{l}\text { All } \\
\text { pensions }{ }^{\mathrm{a}}\end{array}$ & $\begin{array}{l}\text { Old-age } \\
\text { pensions }\end{array}$ & $\begin{array}{l}\text { All } \\
\text { pensions }{ }^{\mathrm{a}}\end{array}$ & $\begin{array}{l}\text { Old-age } \\
\text { pensions }\end{array}$ \\
\hline Total $^{b}$ & $1,314,388$ & n. a. & $1,703,300$ & n. a. & $2,000,523$ & n. a. \\
\hline Paid abroad ${ }^{b}$ & 53,358 & n. a. & 64,151 & n. a. & 78,783 & n. a. \\
\hline $\ln \%$ & $4.1 \%$ & n. a. & $3.8 \%$ & n. a. & $3.9 \%$ & n. a. \\
\hline \multicolumn{7}{|l|}{ France } \\
\hline & \multicolumn{2}{|l|}{2004} & \multicolumn{2}{|l|}{2010} & \multicolumn{2}{|l|}{2012} \\
\hline $\begin{array}{l}\text { Amount in euro (in } \\
\text { thousands) }\end{array}$ & $\begin{array}{l}\text { All } \\
\text { pensions }{ }^{\mathrm{a}}\end{array}$ & $\begin{array}{l}\text { Old-age } \\
\text { pensions }\end{array}$ & $\begin{array}{l}\text { All } \\
\text { pensions }{ }^{\mathrm{a}}\end{array}$ & $\begin{array}{l}\text { Old-age } \\
\text { pensions }\end{array}$ & $\begin{array}{l}\text { All } \\
\text { pensions }{ }^{\mathrm{a}}\end{array}$ & $\begin{array}{l}\text { Old-age } \\
\text { pensions }\end{array}$ \\
\hline Total $^{c}$ & $224,087,790$ & $170,930,510$ & $286,139,250$ & $240,094,700$ & $314,750,890$ & $249,740,950$ \\
\hline Paid abroad ${ }^{d}$ & $4,055,016$ & $3,835,745$ & $6,005,777$ & $5,781,392$ & $6,282,827$ & $6,082,105$ \\
\hline $\ln \%$ & $1.8 \%$ & $2.2 \%$ & $2.1 \%$ & $2.4 \%$ & $2.0 \%$ & $2.4 \%$ \\
\hline
\end{tabular}

Sources: Austria: Hauptverband der oesterreichischen Sozialversicherunsgtraeger, Oesterreichische Sozialversicherung in Zahlen, jaehrlich

Germany: Deutsche Rentenversicherung, Rentenbestand am 31.12, jaehrlich

Belgium: Office National des Pension (ONP), Statistic annuelle des beneficiaires de prestations

France: Centre des Liaisons Européennes et Internationales de Sécurité Sociale (CLEISS), annuelle

${ }^{a}$ Includes beside old-age pensions also survivors and disability pensions, where applicable

${ }^{b}$ Monthly payment, workers and self-employed (ONP)

${ }^{\mathrm{C}}$ Yearly total expenditure (Eurostat)

${ }^{\mathrm{d}}$ Yearly expenditure (CLEISS)

(Holzmann and Pouget 2012). For foreign workers moving to another country for work, returning to their home country, or retiring in a third country, what matters is that benefits in disbursement or rights in accumulation are not forfeited (that is, benefits in disbursement are exportable and rights in accumulation are fully portable to the new country of residence).

In principle, there should be little objection to benefit exportability and acquired rights portability if they are based on prior contributions and eligibility is established 
according to the contingency of the (social) insurance contract: they are essentially akin to property rights. Both migrant-sending and migrant-receiving countries should be interested in making benefits easily portable, as this enhances the advantages of an internationally mobile labor force. If factors for benefit eligibility or its termination (for example, number of children, end of unemployment, end of sickness, or end of life) cannot be properly observed abroad, however, then exportability of social benefits may become restricted. Furthermore, acquired rights based on contribution financing have a major savings component that by itself is not easily established; consequently, neither is the correct amount due for transfer. Even if acquired rights are fully aligned with individual contribution efforts, social benefits typically contain often a major redistributive component that is difficult to establish; even more difficult is determining how much to transfer across borders or to be repaid.

This policy research paper focuses on the functioning of bilateral social security agreements (BSSAs) based on four migration corridor studies undertaken during 2013/ 2014 under a World Bank project. The paper thus fills an important institutional knowledge gap in the policy discourse of international labor mobility. While the portability of social security has received increasing attention over the last decade-starting essentially with Holzmann et al. (2005) and including a recent review of literature (Taha et al. 2015) - no attempt has been made to date to explore the functioning of its claimed key institution: BSSAs. Do BSSAs really deliver on what is expected and what are the key areas of concern and improvement? The Austria-Turkey, Germany-Turkey, Belgium-Morocco, and France-Morocco corridors represent well-established migration corridors that reflect both similarities and differences. ${ }^{2}$ These similarities and differences across the selected corridors allow for some first conclusions and offer insights to formulate recommendations for policy reforms and next research steps.

The structure of the paper is as follows: Section 2 contains a brief introduction to the basic conceptual issues on portability. The objectives, methodology, and process for the four corridor studies are presented in Section 3. Section 4 highlights the similarities and differences in the BSSAs' workings across the four migration corridors. Section 5 summarizes the extent to which the BSSAs fulfill the three proposed evaluation criteria. Finally, Section 6 offers conclusions and recommendations.

\section{Conceptual considerations on the international portability of social benefits}

Discussions and agreements on policies and their instruments fare better if there is a shared understanding of their objectives and conceptual underpinnings. If divergent interests exist between different parties, such an understanding helps identify the source of the differences. The working definition of portability used herein is: "Portability is defined as the ability to preserve, maintain, and transfer social insurance rights vested or on disbursement, independent of nationality and country of residence." ${ }^{3}$

To offer a conceptual background around this definition and the issues presented in the later sections, this section briefly discusses six conceptual domains (drawing on Holzmann and Koettl 2015 and Holzmann et al. 2005):

(a) The three key dimensions of interest in portability

(b)The prevalence of portability between countries 
(c) Difficulty in establishing portability

(d)Benefits that should be portable

(e) Policy options to establish portability

(f) Criteria for the selection of portability instruments

\subsection{Three key dimensions of interest in portability}

In principle, establishing portability of social benefits should be straightforward, as three key considerations-economic, social, and human rights (Holzmann and Koettl 2015)-favor it.

From a first-best economic point of view, an individual's labor mobility decisions should not be influenced by the lack of portability of social benefits for which she/he has established acquired rights. Efficiency is increased by the absence of any distortionary obstacles toward portability. ${ }^{4}$

From a social policy point of view, such acquired rights are a critical element of an individual's (or family's) life cycle planning and social risk management. Denying portability, particularly once the mobility decision has been made and cannot be reversed, risks upsetting the life cycle planning of individuals and families and creating substantial welfare loss.

From a human rights point of view, individuals have the right to social protection according to national legislation and international conventions and these rights should carry over when they leave the country or profession. A key question is whether these human rights apply only to acquired (contributory) rights or to all social rights. As they are resource consuming, economic and social trade-offs will emerge.

\subsection{The prevalence of portability between countries}

Despite this rosy picture on the desirability of portability, the reality is more sobering. Table 2 offers the magnitude of portability regimes by countries' income group: Regime I (portability) signals the existence of a BSSA independent of its depth but typically covering pension benefits. Regime II (exportability) indicates migrants in countries that have no BSSA with their home country but allow the export of cash benefits, once eligibility is established. Regime III (no access) indicates migrants in countries with no access to social insurance programs, which means no mandated contribution obligation but also no pension or other benefits on return. Regime IV (informal) offers an estimate of the share of migrants who are informal in the country, with no contributions to pay and no benefits to take back.

Only $23 \%$ of the stock of migrants in the world are subject to BSSAs, and of this favored group, the large majority ( $86 \%$ ) are migrants from high-income countries living in other high-income countries. These estimates, based on dated 2000 migrant data, may have improved somewhat due to, among other things, the EU's proliferation of portability legislation and its conclusion of framework agreements with several neighboring countries.

A large share of migrants (55\%) live and work in countries that allow cash benefits, once established, to be exported (often restricted to pension-related benefits). However, this may still not happen, as many countries have waiting periods of 10 or more years. 
Table 2 Global migrant stock estimates by origin country income group and portability regime,

\begin{tabular}{|c|c|c|c|c|c|}
\hline Origin country income group & $\begin{array}{l}\text { Regime I } \\
\text { (portability) }\end{array}$ & $\begin{array}{l}\text { Regime } \|^{\mathrm{a}} \\
\text { (exportability) }\end{array}$ & $\begin{array}{l}\text { Regime } \\
I I I^{b} \text { (no } \\
\text { access) }\end{array}$ & $\begin{array}{l}\text { Regime } \\
\text { IV }^{\mathrm{C}} \\
\text { (informal) }\end{array}$ & Total \\
\hline Low-income countries (number) & 850,985 & $36,720,832$ & $5,293,338$ & $10,757,086$ & $53,622,241$ \\
\hline$\%$ of total & 2 & 68 & 10 & 20 & 100 \\
\hline Lower-middle-income countries (number) & $11,312,511$ & $47,224,671$ & $3,476,163$ & $14,473,805$ & $76,487,150$ \\
\hline$\%$ of total & 15 & 62 & 5 & 19 & 100 \\
\hline Upper-middle-income countries (number) & $3,521,212$ & $10,724,671$ & 189,357 & $7,203,975$ & $21,639,215$ \\
\hline$\%$ of total & 16 & 50 & 1 & 33 & 100 \\
\hline $\begin{array}{l}\text { Non-Organisation for Economic Co-operation } \\
\text { and Development (OECD) high-income coun- } \\
\text { tries (number) }\end{array}$ & $2,063,914$ & $3,534,415$ & 192,987 & 57,809 & $5,849,125$ \\
\hline$\%$ of total & 35 & 60 & 3 & 1 & 100 \\
\hline OECD high-income countries (number) & $24,778,310$ & $3,658,850$ & 291,007 & 189,802 & $28,917,969$ \\
\hline$\%$ of total & 86 & 13 & 1 & 1 & 100 \\
\hline Total (number) & $42,526,932$ & $101,863,439$ & $9,442,852$ & $32,682,476$ & $186,515,699$ \\
\hline
\end{tabular}

Source: Holzmann and Koettl 2015, based on Avato et al. 2010 and Holzmann et al. 2005

a Legal migrants with access to social security in the host country in the absence of a bilateral or multilateral arrangement

begal migrants without access to social security in their host country

'Undocumented immigrants

While the number of BSSAs between developed and developing countries has increased over the years, they may still be of limited value to migrants from countries with low coverage rates. These migrants typically come to developed countries with no or limited acquired rights, and if they return to their (low-income) home country before retirement, few acquired rights may be added. This limits the benefits to those who acquire rights abroad under social insurance provisions, and the loss of top-ups and the lower quality of health care services may lead individuals to choose not to return.

\subsection{Why is portability difficult to establish?}

Political support for portability across countries is typically limited, as immobile labor by far dominates mobile labor in both volume and influence. This is evident in countries where mobility between the public and private sectors remains limited and special schemes remain in place. This lack of political support is consistent with the development of national schemes, which typically started with narrowly focused coverage on sectors (trades) and then expanded from civil servants to white- and then blue-collar workers, to farmers and the self-employed, and lastly to the voluntarily insured. This fragmentation within countries is not conducive to establishing portability across countries. Thus, portability considerations for the design and implementation of schemes have only slowly been incorporated, coinciding with the rise in labor mobility. However, domestic considerations are still given priority in the social protection area (unless they contradict EU objectives or ratified International Labour Organization (ILO) conventions). The situation is similar or worse in countries where benefit eligibility is linked to length of residency. Portability of benefits is, at first sight, an alien concept.

Technical reasons for limited portability are largely linked to the following: 
(a) The pseudo insurance nature of benefit determination, which does not allow a straightforward split of acquired rights into (i) a contemporaneous insurance component that is consumed in any period and hence incurs no portability issue; (ii) a pre-savings component that all benefits have to some extent and that could be made portable if its value could be easily established; and (iii) a redistributive component within and between benefit cohorts that can be huge (as in the case of traditional defined pension benefit schemes or health care benefits based on incomerelated contributions). The redistributive character of benefits is responsible for long vesting periods that internationally mobile workers may not fulfill in a single country but could easily if the insurance periods in all countries were added up (that is, totalized).

(b) The tax treatment of contributions and benefits that allows for front- or backloading of taxation for the three stages of contribution payment, return receipt, and benefit disbursement under a tax-exempt-exempt or exempt-exempt-tax regime, respectively. This leads to tax expenditures under an exempt-exempt-tax regime that are not necessarily recovered or reimbursed with a mobile workforce. Tax considerations are one main reason why even migrant-perfect (funded or unfunded) defined contribution (DC) plans continue to meet major obstacles in cross-country portability, albeit the savings component is clear and the redistributive component typically nil.

\subsection{Which benefits should be portable?}

For what benefit types of social security does one want to establish portability: for all or only a subset and based on what criteria?

Social security covers both social insurance and social assistance programs. The difference can be framed through the financing-social security contributions versus general government financing-but is also related to the contingencies to be covered and the extent to which they lend themselves to insurance considerations or reflect general redistributive/anti-poverty considerations.

An incomplete list of social security benefits to consider includes the following:

- Old-age benefits

- Disability benefits

- Survivor's benefits

- Workers' accident and occupational diseases

- Sick pay and maternity benefits

- Severance pay

- Unemployment benefits

- Family benefits (such as children/family allowance)

- Health care benefits

- Long-term care benefits for the elderly

- Income replacement benefits for the care of children and sick or elderly people

While all benefits may be important from a social policy angle, not all are relevant from a labor market standpoint, as not all bias mobility decisions in a relevant manner. 
For such decisions, the long-term benefits-old-age and health care-are quite likely the most important. Furthermore, for a number of the contingencies listed above, it is difficult to determine the "state of the world," that is, whether the risk situation (for example, unemployment) is still valid. In others, the quantities (for example, number of children) or price (for example, long-term care costs) cannot be correctly observed. Thus, cost-benefit considerations are required that may call for a more comprehensive benefit package for a set of countries with tight labor market integration (such as within the EU) than that for country corridors with separate labor markets and unidirectional labor flows.

\subsection{Policy options to establish portability}

Essentially two approaches are used to establish portability: (a) changing the benefit design to make benefits as portable as possible without government action and (b) establishing portability arrangements at the unilateral, bilateral, and/or multilateral level. These two approaches are both substitutes and complements.

The key feature of changing the benefit design is to distinguish explicitly between the period insurance element and the pre-funding element of social benefits in addition to making any redistributive action outside the benefit scheme. While this may have limited bearing on the portability of benefits in disbursement, having a clearly identified pre-funding element should substantially ease portability for all social insurance-type benefits, except, perhaps, family benefits. For cash benefits, this is accommodated by the (partial or full) move from a defined benefit (DB) to a DC-type structure. DC benefits are inherently more portable than defined DBs.

A range of portability arrangements can be used to enhance or fully establish portability. Most portability discussions focus on BSSAs, but the scope of arrangements is much larger and includes the following:

- Unilateral actions (UAs): UAs can be taken by a country when individuals have established acquired rights; UAs can improve portability through full exportability of benefits in disbursement and of acquired rights.

- BSSAs: BSSAs are the centerpiece of current portability arrangements between countries. While in principle, they can cover the whole range of exportable social benefits, BSSAs focus mostly on long-term benefits such as old-age, survivor's, and disability pensions and, to a much lesser extent, on health care benefits. ${ }^{5}$

- Multilateral Arrangements (Mas): MAs represent a general framework of portability for a group of countries for all or a subset of social benefits. These general rules are typically supported by more detailed BSSAs. The best known and most developed MA is the one among EU member states that is actually not an MA but a decree-based instrument that creates supranational EU law. Traditional MAs have been established in Latin America (MERCOSUR) and the Caribbean (CARICOM) and in 15 French-speaking countries in Africa (CIPRES); one was recently established between Latin America and Spain and Portugal (Ibero-American Social Security Convention); and one is under development for the Association of Southeast Asian Nations (ASEAN) countries. The EU is also leading efforts to enhance social security cooperation within the Euro-Mediterranean Partnership. ${ }^{6}$ 
- Multinational providers (MPs): A promising approach is to use the services of multinational (private sector) providers, at least for supplementary benefits in health care and old age. MPs exist and function well for health care benefits; for example, Vanbreda (recently renamed Cigna), a Belgium service provider, services World Bank staff and retirees residing in Europe and is used by the European University Institute. MP arrangements have been discussed and sometimes implemented, for supplementary pensions of international workers in multinational enterprises.

\subsection{Considerations and criteria for the selection of portability instruments}

A variety of considerations (objectives) can be raised to support the demand for full portability of social benefits. Ultimately, they boil down to two: fairness and efficiency.

Fairness considerations can be raised at the individual and country levels. If an individual has contributed (mandatorily or voluntarily) to programs to mitigate future risks to allow him/her to smooth consumption across the main risks in his life, then acquired rights should be portable over time and between countries, as a matter of fairness. Similar considerations apply at the country level. If an individual moves between countries, denying him/her portability of acquired rights provides a windfall profit for the home country while potentially burdening his/her new host country, both of which are unfair.

Efficiency considerations of portability are closely linked with the labor market but go beyond. Full portability should render the labor mobility, labor supply, and residence decision independent of social benefits. In the absence of full portability, individuals (and families) may decide not to migrate or return or may decide to offer labor in the informal sector, possibly with stark implications for the overall tax revenues and economic growth of their home country.

To assess whether portability arrangements succeed in delivering on fairness and efficiency considerations, three broad results criteria have been suggested (Holzmann et al. 2005; Holzmann and Koettl 2015) and are used in this paper:

- Criteria 1: No benefit disadvantage with regard to pension and health care for migrants and their dependents. Movements between host countries or back to the home country should not lead to lower pension benefits or gaps in health coverage than if one stayed in one country.

- Criteria 2: Fiscal fairness for host and home countries. No financial burden should arise for the social security institution of one country while the social security institutions of the other country benefit from any provisions on portability or the lack thereof.

- Criteria 3: Bureaucratic effectiveness. The administrative handling of portability should not cause an undue bureaucratic burden for the countries' institutions involved and should be easy to handle for migrants.

\section{Investigating the four BSSAs: design and implementation}

BSSAs establish the portability of social benefits between two countries and thereby serve multiple goals, including defining which social benefits will be coordinated 
("material scope"); defining the individuals covered under the agreement ("personal scope"); establishing the depth of coordination (from time-limited exemptions to contribute to the host scheme to exportability of benefits to full-fledged coordination); and establishing coordination on eligibility criteria, benefit calculation, disbursement, service delivery, financing, and processes of application, decision, and information. ${ }^{7}$

To be effective, to deliver on their overall objective, and to detail their goals, BSSAs should ensure the following:

- Equality of treatment: This refers to the principle that all workers engaged in remunerated labor should enjoy equal provision of social security; this provision can also be extended to workers' dependent family members.

- Payment of benefits abroad (exportability): The principle provides for any acquired right, or right in the course of acquisition, to be guaranteed to a migrant worker in one territory even if it has been acquired in another.

- Determination of applicable legislation: This principle ensures that the social security of a migrant worker is governed at any one time by the legislation of only one country. Three basic rules apply:

Employees are covered by the legislation of the contracting country in which they work, even if they reside in the other contracting country.

Self-employed persons are covered by the legislation of the contracting country in which they perform their economic activity.

Civil servants are covered by the legislation of the contracting country within whose administration they are employed.

- Maintenance of benefits in the course of acquisition (totalization): This principle provides that when a right is conditional upon the completion of a qualifying period, a migrant worker's periods of employment in each country are considered.

- Administrative assistance: This principle aims to provide for mutual administrative assistance between the social security authorities and institutions of participating members.

BSSAs between countries are considered by most or all of the social security profession as the key instrument to establish portability for mobile workers. Although some call the approach "state of the art," no substantiated proof exists for such an assertion. Neither a regional nor a worldwide inventory of BSSAs has been conducted to describe their basic features in a comprehensive, analytical way (for example, type of benefits covered, depth and type of coordination on such benefits). To the author's knowledge, no other qualitative study even less so any quantitative analysis has ever been undertaken and published to explore the functioning of BSSAs, to highlight the strengths and weakness of their operation, or to evaluate them against predefined criteria ${ }^{8}$; this assessment resonates with a recent review of literature (Taha et al. 2015). A very first and incomplete attempt in this direction was undertaken by Holzmann et al. (2005) based on information gathered for a few migration corridors. While incomplete, the study showed the potential power of corridor studies. Corridor studies have some tradition in the analysis of migration flows and integration issues. ${ }^{9}$

BSSAs in four corridors with two migrant-sending and four migrant-receiving countries were chosen for this study-Morocco's agreements with Belgium and France and 
Turkey's with Austria and Germany. The selection of corridors was guided by considerations of (a) proximity of migrant-sending country pairs, to allow for better comparability of differences and (b) diversity with regard to experience. The Austria/GermanyTurkey agreements are considered mature and advanced, as they included health benefits from the beginning. The Belgium/France-Morocco agreements included some other short-term benefits from the beginning but were only recently revised to include/ propose comprehensive health care benefits.

To put the four corridors and their BSSAs into perspective, Table 3 presents the number of BSSAs for each country across the corridors. The data for the USA and Japan are included for comparison. The picture that emerges is straightforward. In contrast to other main industrialized countries in the world-Australia, Canada, Korea, Japan, and the USA - all European host countries have a focus on the Balkans and northern Africa as relevant migration destinations, while those with a colonial past (particularly France) also favor Sub-Saharan Africa. The sending countries have BSSAs with other main European countries and Canada plus a number of neighboring countries. In contrast, Japan and the US' BSSAs are only with other highly industrialized countries, with one exception each for an emerging economy (Brazil and Chile, respectively). This is particularly surprising for the USA, which has main migration corridors with essentially all countries in Latin America and the Caribbean and a very strong one with Mexico. For the latter migration corridor, a BSSA was drafted in 2004 but has not yet been signed and implemented.

The research focused on each BSSA's effectiveness in facilitating portability of pensions (old-age, disability, survivor's) and health care benefits, as these are the core (or only) benefits typically covered by BSSAs between southern and northern countries. In addition, the analysis covered family benefits (family allowances), as their history and current status differ markedly across the corridors. Thus, the selected corridors provide a useful starting point for understanding the functioning of BSSAs, as their scope of

Table 3 Number of bilateral social security agreements across corridor countries in 2015

\begin{tabular}{lll}
\hline Country & Number of BSSAs & Of which, south-north partner countries \\
\hline Austria & 15 & Bosnia-Herzegovina, Moldavia, Montenegro, Philippines, Serbia, Tunisia, Uruguay \\
Germany & 17 & $\begin{array}{l}\text { Bosnia-Herzegovina, Kosovo, Macedonia FYR, Morocco, Montenegro, Serbia, } \\
\text { Tunisia, Uruguay }\end{array}$ \\
Turkey & 22 & $\begin{array}{l}\text { Belgium, Canada, Denmark, France, Luxemburg, Norway, Netherlands, Sweden, } \\
\text { Switzerland }\end{array}$ \\
Belgium & 25 & $\begin{array}{l}\text { Albania, Algeria, Congo, Dem. Rep., Bosnia-Herzegovina, India, Kosovo, } \\
\text { Macedonia, Moldavia, Philippines, Serbia, Tunisia }\end{array}$ \\
France & 41 & Algeria, Benin, Bosnia-Herzegovina, Cameroon, Congo, Dem. Rep., Gabon, Mali, \\
& Niger, Philippines, Tunisia, Turkey \\
Morocco & 16 & Canada, Germany, Denmark, Spain, Netherlands, Quebec, Sweden \\
USA $^{c}$ & 25 & Chile \\
Japan & 15 & Brazil
\end{tabular}

Source: National Social Security Institutions

aSSA signed and enacted as of 2015

${ }^{\mathrm{b}}$ For EU countries, 31 more corridor arrangements are added resulting from the other 27 member states plus the other four countries within the European Economic Space that have the same legal status (Iceland, Lichtenstein, Norway, and Switzerland)

${ }^{c}$ All other BSSAs are with European countries, Australia, Japan, and Korea, and no developing or emerging economy

dAll other BSSAs are with European countries, Australia, Korea, and the USA, and no developing or further

emerging economy 
coverage varies somewhat over time, as do the history and relationships between the signatories, but the principles on which they are based are largely similar.

The corridor study approach comprised preparation of three main sets of background documents before evaluating each BSSA against the three criteria. The first set of documents concerns country and corridor profiles on relevant topics. The second set relates to development of a relevant dataset and selection of key performance indicators. The final set contains the minutes of in-depth interviews with key stakeholders in the BSSA process.

In the first set of documents, the respective researchers established four types of profile documents relevant to the BSSA for each corridor: (a) a migration profile that sketches migration stocks and flows and key labor market characteristics for the corridor countries; (b) social insurance profiles of each corridor country, with a focus on portability-relevant contingencies; (c) a profile of the BSSA, including benefits covered, rules/instruments applied to achieve portability, rules of coordination, motivation for the BSSA, and special issues; and (d) a profile of each country's national social insurance institutions and their administrative support for BSSAs, with a focus on administrative arrangements and processes (for example, information and communication technology support, application, decision, and disbursement), compared to national applicants and international best practice.

Work on the second set of documents started with identification of a wish-list of data considered desirable and relevant for the analysis, with the intent to develop a result matrix that would bring together the BSSA's objectives and outcomes (as measured against the three criteria) with the related inputs, including the BSSA's regulations. It soon became apparent that the desired data were extremely sparse and often simply not available or comparable across countries, impeding researchers' ability to implement this approach in full. For example, some countries' data do not distinguish whether host country nationals living abroad (to whom pensions are distributed) are return migrants or temporary residents (snowbirds). Further, the level of naturalization across all corridors is remarkable, albeit not identical. All else constant, different levels of naturalization lead to different numbers of people remaining with a foreign passport, while the number of those born abroad is the same. As some countries do not allow collection of information about those born abroad, determining who receives a pension abroad gets complicated. As a result, the initial objective to develop and use a set of key performance indicators had to be dropped due to lack and/or comparability of relevant data.

The third set of documents consisted of in-depth interviews undertaken with two types of participants in the BSSA process: (a) representatives from ministries and/ or social security institutions in charge of BSSA design and implementation and (b) nongovernmental organizations involved in the topic, such as migrants' associations. This qualitative research proved very productive to gain major insights into substance, process, and issues around portability and BSSAs. While the interviews are referred to in the corridor studies, for reasons of confidentiality, they cannot be made public.

Based on these country-specific documents and a first joint assessment of BSSAs in the east corridor (Austria and Germany with Turkey) and in the west corridor (Belgium and France with Morocco), ${ }^{10}$ individual corridor studies were prepared. ${ }^{11}$ 


\section{Similarities and differences of BSSAs across the four migration corridors}

By design of the selection process, the four corridors and their BSSAs have a number of similarities. However, the analyses revealed similarities that go well beyond the obvious. A number of idiosyncratic and systemic differences emerge that reflect the political preferences of the respective migrant-receiving and migrant-sending countries.

To explore and present the BSSAs' similarities and differences, Section 4 is structured as follows: Section 4.1 describes the migration history of the four corridors; Section 4.2 highlights the contents of the four corridors' BSSAs and offers a summary evaluation; Section 4.3 and Section 4.4 offer the details of pension and health care benefits, respectively; and Section 4.5 briefly presents information on family benefits, as this topic had the most divergent results of all benefits covered under the BSSAs.

\subsection{Migration developments}

In all four migration corridors, the BSSAs' origins are found in the labor migration of the 1960s and the reaction to post-World War II labor shortages in Austria, Germany, Belgium, and France. Migration flows have existed between Morocco and France (and to some extent Belgium) since World War I and World War II, given the participation of Moroccan soldiers on the side of the allies, but this was mostly war related and temporary. No sizable migration flows existed between Turkey and Austria/Germany before $1960 .{ }^{12}$ The relocation of civil populations between the two wars from and to the former Turkish Empire was one of the largest government-sponsored relocations in mankind (Manning 2013).

Migration from the early/mid-1960s to $1973 / 74$ was a publicly organized labor flow between participating migrant-sending and migrant-receiving countries. By objective and design, the flow was temporary, with little concern for family unification or longterm prospects in the migrant-receiving country. The four corridors' BSSAs from the 1960s served as instruments of attraction and competitiveness; similar BSSAs were signed with the former Yugoslavia by Austria and Germany and by Belgium and France with Algeria and Tunisia.

The first oil price crisis in 1973 changed the migration regime and outlook, as largescale labor recruitment was abruptly stopped and never resumed. Furthermore, over the next 10 years or so, a number of one-off actions were initiated in some countries to induce temporary migrants to return home voluntarily. For those (and the majority) who decided to stay on, family unification became important and dominant in the migration flows. In addition, a constant flow of labor migrants continued on all corridors at a lower scale. The data indicate larger gross flows of immigration and return migration, with net flows partly negative for Austria and Germany in recent years.

Estimating the stock of migrants from the two migrant-sending countries in the respective migrant-receiving countries is complicated due to naturalization-which differs both in nature and scope between the east and west corridors. In all corridors, the first (and second) generation has given rise to the second and third generations born in the migrant-receiving country. In Belgium and France, this gives rise to the right of citizenship latest at the age of majority as the principle of "ius solis" applies; in addition, newcomers may acquire citizenship according to the rule of time of presence and gainful occupation. In Austria and Germany, the principle of "ius sanguinis" applies, whereby 
the right to citizenship depends on at least one parent having citizenship, while again newcomers may acquire citizenship according to the rule of time of presence and gainful occupation, although the specific criteria have changed over time.

As a result, the naturalization rate between Austria-Germany and Belgium-France differs, while the share of individuals with a migration background does not. Furthermore, the national data in France and Belgium do not allow differentiation of individuals by their place of birth/ethnicity. Hence, a pension sent from France or Belgium to a resident in Morocco can be differentiated by the resident's nationality (assuming $\mathrm{s} / \mathrm{he}$ has only one), but if it is a French or Belgian citizen, no differentiation can be made based on his/her ethnic background/country of birth.

Table 4 offers a summary of data and estimates on the number of individuals with a migration background in their respective migrant-receiving countries and their significance in the respective corridors' migrant-sending countries.

Table 4 exhibits the similarities and differences between the corridors and countries. Overall, the share of population with a migration background is strikingly similar in all four migrant-receiving countries, ranging from 17.7 to $19.5 \%$. These data and the notion of individuals with a migration background are relatively well-defined and used in Austria and Germany (albeit not strictly comparably even between these countries). Migration background is not legally defined in Belgium and France, but the concept is used by researchers to estimate comparable data. The definition typically comprises individuals born abroad or to parents of whom at least one was also born abroad or as foreigner (that is, the second generation). Across the four migrant-receiving corridor countries, almost one person in five is considered to have a migration background.

For the two migrant-sending countries, the data indicate broad similarities, but Austria and Germany's populations have slightly more residents with a Turkish background (3.3 and $3.6 \%$, respectively) compared to Belgium and France's share of the population with a Moroccan background ( 2.1 and $2.9 \%$, respectively).

The share of those from migrant-sending countries who keep their original citizenship (and are not yet naturalized) is telling and not surprising. In countries with the principle of "ius solis," only about $0.7 \%$ of the total population, or one third to one quarter of the population with the respective background population, live as foreigners in the migrant-receiving country. Both values are much higher in countries with the principle of "ius sanguinis": 1.3 and $2.0 \%$, respectively. As result, less than half of the

Table 4 Population, migration background, and foreign citizenship

\begin{tabular}{|c|c|c|c|c|c|c|c|}
\hline \multirow[b]{2}{*}{ Austria (2012) } & \multirow{2}{*}{$\begin{array}{l}\text { Population (in thousands) } \\
8452\end{array}$} & \multicolumn{2}{|c|}{$\begin{array}{l}\text { Of which, with } \\
\text { migration background } \\
\text { (in thousands) (\%) }\end{array}$} & \multicolumn{2}{|c|}{$\begin{array}{l}\text { Of which, with } \\
\text { Turkey/Morocco } \\
\text { migration } \\
\text { background (in } \\
\text { thousands) (\%) }\end{array}$} & \multicolumn{2}{|c|}{$\begin{array}{l}\text { Of which, with } \\
\text { Turkey/Morocco } \\
\text { citizenship (in } \\
\text { thousands) (\%) }\end{array}$} \\
\hline & & 1600 & 17.7 & 275 & 3.3 & 113 & 1.3 \\
\hline Germany (2011) & 81,754 & 15,962 & 19.5 & 2956 & 3.6 & 1607 & 2.0 \\
\hline Belgium (2011) & 10,951 & $2023(2005)^{\mathrm{a}}$ & 19.3 & $290^{\mathrm{a}}$ & 2.9 & 80 & 0.7 \\
\hline France (2011) & 63,294 & $11,800(2008)^{b}$ & 18.6 & $1314(2008)^{b}$ & 2.1 & $435(2010)^{c}$ & 0.7 \\
\hline
\end{tabular}

Source: Corridor studies; Poulain and Perrin 2008; Wikipedia: Demographics of Belgium; Demographics in France; INSSE recensement 2008 and INSSE recensement 2010

apoulain and Perrin 2008

bINSSE recensement 2008

'INSSE recensement 2010 
population with a Turkish background have German citizenship and less than $40 \%$ have Austrian citizenship. The differences between Germany and Austria also reveal differences in their naturalization processes.

\subsection{The BSSAs in the four corridors}

All four BSSAs date from the mid-/late-1960s and have seen few changes (Table 5). Austria and Germany's BSSAs are essentially unchanged except for corrections in scope (Austria) and process (Germany). Belgium and France's BSSAs had an even longer shelf life and were revised only recently; most importantly, they added an extension in health coverage.

The individual BSSAs' scopes of coverage are quite different and are aligned by east and west corridors (Table 6). The Austria-Turkey and Germany-Turkey BSSAs focus essentially on pensions and health; health was included from the very beginning, an outlier among the BSSAs then (and to some extent even now). Family allowances were included initially but eliminated in the Austria-Turkey BSSA when it was canceled in 1996 (and not included in the otherwise identical BSSA of 2000).

From the very beginning, the BSSAs for Belgium-Morocco and France-Morocco had a larger scope of benefits in cash but until their recent revisions did not include portability of health care benefits for retirees, as mandatory health care insurance coverage was introduced in Morocco only in 2005.

All four BSSAs studied are based on the same two basic principles of BSSAs. Portability of social benefits exists only (a) for those based on contributions/acquired rights (that is, principle of contribution base) and (b) for which a corresponding benefit exists in the other country (that is, principle of reciprocity). However, the latter principle is violated by the payment of family benefits, which exists in Germany but not in Turkey.

The following picture and questions emerge from the initial and summary assessment of the BSSAs in these four corridors that are detailed in the subsections below:

- The four BSSAs reflect the migration situation of decades ago and the labor market goals of the 1950s and 1960s. Albeit significant changes have occurred in both the migration and labor market situation, relatively few changes have taken place in these BSSAs over the years. Revision of the two BSSAs in the west corridor has proven to be lengthy and difficult.

Table 5 The origin and status of the BSSAs

\begin{tabular}{llll}
\hline & $\begin{array}{l}\text { Date of first } \\
\text { BSSA }\end{array}$ & Date of current BSSA & Envisaged revision \\
\hline $\begin{array}{l}\text { Austria- } \\
\text { Turkey }\end{array}$ & 1966 & $\begin{array}{l}\text { 2000, unchanged except family allowance 1966 BSSA } \\
\text { terminated in 1996 }\end{array}$ & Not at the moment \\
$\begin{array}{l}\text { Germany- } \\
\text { Turkey }\end{array}$ & 1964 & $\begin{array}{l}\text { 1984 Suppl. Aide Memoire (AM), 1974 Interim AM, } \\
\text { 1969 Changing AM }\end{array}$ & Not at the moment \\
$\begin{array}{l}\text { Belgium- } \\
\text { Morocco }\end{array}$ & 1968 & $\begin{array}{l}\text { May 2014, with Administrative Agreement, effective } \\
\text { as of May 1 }\end{array}$ & $\begin{array}{l}\text { Partial revision under } \\
\text { implementation }\end{array}$ \\
$\begin{array}{l}\text { France- } \\
\text { Morocco }\end{array}$ & 1965 & May 2011, with convention as of October 2007 & $\begin{array}{l}\text { Revision under } \\
\text { implementation }\end{array}$ \\
\hline
\end{tabular}

Source: Holzmann et al. 2016a, 2016b, 2016c, 2016d 
Table 6 Scope of benefit coverage under the four BSSA corridors (as of January 2015)

\begin{tabular}{llll}
\hline Austria-Turkey & Germany-Turkey & Belgium-Morocco & France-Morocco \\
\hline - Retirement pension & - Retirement pension & - Retirement pension & - Retirement pension \\
- Survivor's pension & - Survivor's pension & - Survivor's pension & - Survivor's pension \\
- Invalidity benefits & - Invalidity benefits & - Invalidity benefits & - Invalidity benefits \\
- Health insurance & - Health insurance & - Health insurance & - Health insurance \\
benefits & benefits & benefits & benefits \\
- Occupational diseases & - Occupational diseases & - Occupational diseases & - Occupational diseases \\
- Work injuries & - Work injuries & - Work injuries & - Work injuries \\
- (Family allowance ${ }^{\text {a }}$ ) & - Family allowances & - Family allowances & - Family allowances \\
& & - Unemployment benefits & - Unemployment benefits \\
& & - Sickness benefits & - Sickness benefits \\
\hline
\end{tabular}

Source: Holzmann et al. 2016a, 2016b, 2016c, 2016d

anilaterally canceled by Austria in 1996

bUnilaterally covered by Germany and at reduced level for children abroad

${ }^{c}$ Not yet operational

dLimited to four children if paid abroad

- The four BSSAs are broadly similar but quite different in structure and details, and the BSSAs' language is much less harmonized than expected with regard to what and who are covered and how coverage is defined and implemented. The source of these differences is unclear (for example, there are major differences in the BSSAs' underlying institutional setup and structures) as is whether these differences actually matter for the large majority of those insured or only for a few marginal cases.

- For pension benefits in the broad sense (that is, old-age, survivor's, disability, and work injury and occupational diseases), no significant conceptual and operational issues seem to exist, except for the nonexportability of noncontributory benefits (top-ups), administrative issues around documentation readiness and information, and the taxation of benefits in disbursement.

- For health care benefits, more unsolved conceptual and operational issues prevail about how best to establish individual and fiscal fairness, albeit the systems in place broadly deliver the benefits and services due.

- Family benefits and the allowance for children staying in the home country of the (foreign and national) worker remain a topic of conceptual and operational controversy across the four BSSAs.

\subsection{Pension portability}

Seven key issues matter for individuals with acquired pension rights across country borders.

\subsubsection{Totalization of insurance periods}

For waiting periods of individual countries (and thus exclusion from eligibility) to not become effective, totalization of insurance periods is at the core of any BSSA (as far as earnings-related schemes are concerned) and is a feature of all four reviewed BSSAs. The relevance of totalization is proportional to the length of the waiting period (5 years in Germany; 15 years in Austria, as well as in Belgium and France for their first-tier schemes).

\subsubsection{Timely calculation of benefits}

The timeliness of the benefit calculation depends on how records of insurance periods are prepared within individual schemes and on the presence or degree of electronic 
exchange between schemes. Timely preparation and electronic exchange exist in Austria and Germany, are absent in Belgium and France, and are also lacking in Turkey and Morocco. In the latter two countries, information is only put on paper when an application arrives and the exchange between the different funds also takes place in paper form. This substantially lengthens the application process. Turkey plans to apply an electronic format as of 2017. No plans for electronic exchange exist in Morocco. However, since 2013, Caisse Nationale de Securite Sociale (CNSS) has developed electronic forms, for instance, for birth and death certificates. Thus, electronic formats have been partially implemented in Morocco (CNSS) but not to facilitate portability.

To calculate benefits, according to its BSSAs, the east corridor applies only the "direct method"; that is, once eligibility is established, the benefit for each country is calculated according to national rules. According to its BSSAs, the west corridor applies the "European (double) method" and calculates the benefits for the totalized insurance period before assigning each country payments through pro rata apportioning. The result of the pro rata method is compared to that using the direct method, and the better result is selected (see Table 7 for an example). While called the European method, it is not consistently applied between all EU countries (for example, between Austria and Germany). According to interviews with the social security administration, results differ little between the methods, as recent reforms have established closer contribution benefit links.

\subsubsection{Full exportability of acquired rights}

Full exportability of acquired rights (that is, no benefit reduction because of, say, purchasing power considerations) is typically a basic ingredient for a BSSA and has specific relevance if an individual country's legislation imposes reductions when sending the pension benefit abroad. This was the case for German pensions, which paid only $70 \%$ of the pension benefit due if the pension was paid abroad to a country without a BSSA in place (for example, to a Turkish retiree residing in South Africa with a German

Table 7 Example of portable pension benefits calculated with direct and pro rata methods Benefit background and assumption for state $A$ and state $B$

- In state $A$, a full (basic) pension of $€ 800$ per month is paid to those who have been insured for 40 years (2 \% for each year), provided they have been insured for at least 20 years.

- In state $B$, a pension of $50 \%$ of the maximum national pension (€1000) plus $1 \%$ for each year is paid to those who have been insured for at least 25 years; the maximum insurance period considered is 50 years.

- The worker has insurance periods of 18 years in state A and 24 years in state B.

Direct calculation

- No contracting party can pay a pension under national law solely on the insurance period completed on their territory.

- The aggregated (totalized) insurance periods, however, are 42 years and satisfy entitlement conditions in both states.

- State A calculates the pension on 18 years and therefore pays $18 \times 2 \%$ of $€ 800=€ 288$. In state B, $50 \%$ of the maximum national pension does not depend on the length of periods completed, so from this part, only $24 /$ 30 would be payable. State B therefore pays a monthly pension of $24 / 30$ of $50 \%$ of $€ 1000+24 \times 1 \%$ of $€ 1000=€ 400+€ 240=€ 640$. This gives the worker a total pension of $€ 288+€ 640=€ 928$.

Pro rata calculation

- Again, no contracting party can pay a pension under national law but under the totalized insurance periods of 42 years.

- With 42 years of insurance, the theoretical amount for full insurance in state $A$ is $€ 800$ and in state B is $50 \%$ and $42 \times 1 \%$ of $€ 1000=€ 920$.

- Prorating these amounts makes state A pay $18 / 40 \times € 800=€ 360$ per month (note that the fraction used is not $18 / 42$ as the maximum insurance period in state $A$ is 40 years). The pension to be paid by state $B$ is $24 / 42 \times$ $€ 920=€ 526$ (rounded) per month. This gives the worker a total pension of $€ 360+€ 526=€ 886$. 
pension). This regulation was abolished on October 1, 2013 (as only a few pensions were concerned).

\subsubsection{Nonexportability of noncontributory benefits due to lack of reciprocity}

Nonexportability of noncontributory benefits (pension top-ups) is quite likely the most contentious issue in all four corridors. All four investigated EU member countries have some form of minimum income guarantee in old age, with means-tested top-ups granted if the own pension benefit level plus other income is below the guaranteed income level in old age (Ausgleichszulagenrichtsatz fuer Alterspensions in Austria; Garantie de revenus aux personnes âgées in Belgium; Allocation de solidarité pour les personnes âgées in France; and Grundsicherung im Alter in Germany). Yet, none of these EU member countries allow the export of the top-ups to supplement benefits paid abroad.

Table 8 offers the magnitudes of these minimum income guarantees and examples for top-ups as of January 1, 2016. The latter are calculated assuming a common net pension level of $€ 470$ in all countries, an assumed amount of own pension that may be broadly representative of potential return migrants. If correct, the top-up would be higher than the own pension and the total net pension income (own net pension plus top-up) above the average gross labor income in the sending country.

The denial of exportability for these minimum pension guarantees is fully in line with EU legislation and the lack of reciprocity, as neither Morocco nor Turkey offers a minimum old-age income guarantee to its citizens (they do offer minimum pensions for those eligible for a pension benefit, as do their EU counterparts). As the own pension benefit levels of Moroccan and Turkish retirees are typically well below those of their EU counterparts-due to lower wages as well as shorter insurance periods-the share of retirees with Moroccan and Turkish migration background that get such top-ups is much higher, typically one third or more compared to about $10-15 \%$ of the indigenous population.

The lack of exportability of top-ups in addition to the loss of other local benefits and services that old-age residents below the minimum income guarantee typically enjoy (such as for housing, transportation, television fees, leisure activities) plus the loss of access to better health care systems is claimed to contribute to low-return migration of retirees (whether naturalized or with citizenship of the sending country). ${ }^{13}$

\subsubsection{Centralized, efficient application processes}

Application from the country of residency through a dedicated entry point, direct administrative contacts between the diverse insurance funds, and centralized information

Table 8 Minimum income guarantee in old age (€ (rounded) per month as of January 2016)

\begin{tabular}{lllll}
\hline Country & Max guarantee single & Max guarantee couple & Example transfer for couple $^{\text {a }}$ & Comments \\
\hline Austria & 883 & 1324 & 854 & Paid 14 times $^{c}$ \\
Germany $^{\text {b }}$ & 819 & 1143 & 673 & Paid 12 times \\
Belgium & 688 & 1032 & 562 & Paid 12 times \\
France & 800 & 1242 & 772 & Paid 12 times
\end{tabular}

Source: Author, based on information provided on the websites of national social security institutions

${ }^{a}$ Assuming uniformity of own income/pension (net of health contributions) of $€ 470$ per month in each country

${ }^{b}$ Calculated on basic consumption need of $€ 404$ (728) plus acceptable rental costs $(€ 345)$ and heating costs $(€ 70)$ per month

cAustrian salaries and pensions are paid with two extra installments per year (typically for June and December or a half month addition every quarter) and taxed at a low flat rate of $6 \%$ (for singles) 
access and a designated contact person are all conveniences that are not regulated in a BSSA but are part of a country's administrative capacity.

The processing of an application from Morocco and Turkey with insurance periods in Europe only is facilitated by full informatization of insurance records in most of these countries. As a result, applications to the east corridor countries once received by postal communication can be responded in normal cases, by Austria and Germany, with a preliminary approval within days and a definite approval within weeks. If additional written records are required (as may be the case in the western corridor countries), the weeks will become months. If insurance periods were acquired in the sending countries before or after returning home, then their collection and verification can be time-consuming, particularly if the date of birth or name is unclear. If benefit information from the sending country is required to establish totalization or the level of top-ups when residing in the host country, the delay can be substantial as is the loss of benefit disbursement or delayed payment of top-ups.

Turkey envisages moving to full computerization of insurance records by 2017. This may apply to new and some older records, but full computerization of all records is likely to be decades away and, thus, so is a quick application process. No information is available about the ICT plans in Morocco.

\subsubsection{Channels of pension payment}

The benefit payment from a disbursing pension fund to an individual retiree is made directly to an indicated bank account. This also occurs in transnational transactions in the east corridor, whereby a retiree with Turkish residence informs the pension fund of the account in which she/he wants the transfer made, in either Turkish lira or euros. If the latter, the money cannot be touched until the 21st of the month to avoid fees. For ease of transfer, Austria reportedly uses the German Postbank as an intermediary for transfers to Turkey.

In the west corridor, transfers from France are also directly made to a nominated individual bank account in Morocco; in Belgium, transfers are channeled through the contact institution in Morocco (CNSS). In case of direct transfer, an annual proof of life is requested; in the case of CNSS, the proof is processed by the disbursing unit.

\subsubsection{Consistent taxation of pensions}

Consistent taxation of pension benefits is a further requirement for portable pensions. This issue is not addressed in BSSAs but left to bilateral double taxation treaties (DTTs) between countries. The first goal of DTTs is to eliminate international double taxation or to reduce its effects. Most DTTs were established when portable pensions were not yet an issue; as a result, BSSAs and DTTs are often not consistent, and no conceptual guidance is available on how to make them so. The general rule of DTTs is that pension benefits from social security institutions are to be taxed in the country of residency, while those pension benefits from public institutions (that is, civil servants' pensions) are to be taxed by the source country. The reality is much more complex and confusing; the solution awaits a better understanding of what is happening and conceptual guidance on how best to tax (Holzmann 2015; Genser and Holzmann 2016).

Table 8 summarizes the tax treatment between the various BSSA partners. It shows wide variation in taxation approaches, even within these four taxation corridors. Two source countries (Germany and Belgium) tax pensions while two (Austria and France) 
do not. Of the two receiving countries, Turkey does not tax pensions at all (as pensions are not considered taxable income). Morocco taxes pensions but not those from Belgium (which are exempt due to a DTT) and offers very generous income tax allowances for pensions from France (which are not source-taxed there) if the pensions are paid to a Moroccan bank account and used locally.

Such differences in the tax treatment of pensions affect the fiscal neutrality of portability arrangements well beyond those of BSSAs and are discussed again in Section 5.

\subsection{Health care portability}

Portability of health care benefits between countries is well-established within the EU through a network of EU legislation and regulation and special bilateral arrangements. Portability is either absent or only incompletely addressed in EU countries' BSSAs with third countries, however. While BSSAs with European countries outside the EU strive for completeness, this is not the case for BSSAs with countries in other continents. When the material scope does cover health or other benefits, the coverage is often limited (Spiegel 2010). As a result, the worldwide experience with portable health care benefits is much more limited and conceptually and operationally much less streamlined than is the case for pensions.

In this regard, the four BSSAs under investigation are an exception. Austria and Germany's BSSAs with Turkey (and the former Yugoslavia) contained health care coverage from the very beginning. Belgium and France's initial BSSAs with Morocco contained very limited health care elements, as social health care programs were introduced in Morocco only in 2005. The revised BSSAs of Belgium-Morocco (as of 2011) and France-Morocco (not yet signed but with an AM as well as an Administrative Agreement for implementation as of 2014) extend health care benefits to pension benefit recipients in the other country; their introduction is reportedly under implementation (but little information is available about their operation).

Portability of health care benefits for migrant workers can be exemplified for a variety of cases and situations:

(a) A foreign (migrant) worker's access (and any family residing with him) to a host country's mandated health system is usually but not always the same as that of a national worker. For example, waiting periods are typically waived in the BSSA to make workers equal from the very first day. In contrast and as an example, Australia requires migrant workers (and their family members) to be self-covered under a private health insurance contract for the first 2 years of residence and work.

(b) Reciprocal access of workers from the other countries to emergency health care in case of traveling.

(c) Coverage by the home country of the migrant's family left behind in the home country and paid by the host country.

(d)Coverage of visiting family members left behind in the host country in case of emergency.

(e) Coverage of a pension recipient from one country taking residency in the other country.

(f) Temporary coverage of such a residing retiree in the country of pension payment for emergency or pre-agreed treatment. 
While all these (and other) cases may form part of a BSSA, the focus of BSSAs with selected third countries is typically and increasingly focused on contingencies that can be controlled by the paying institutions (Spiegel 2010).

\subsubsection{East corridors' BSSAs and health care portability}

The east corridors' BSSAs (Austria-Turkey and Germany-Turkey) offer an arrangement similar to the treatment within the EU that includes immediate health care coverage for foreign workers; emergency coverage of workers and family members when traveling in the other country; coverage for pre-agreed treatment in the other country; coverage of nonresident family members by their home country institution; and coverage in the country of pension receipt. The last component is typically the most difficult to implement, albeit the issues around medical claims for visiting migrants and family members may create the most complaints.

With respect to family left behind, under the east corridors' BSSAs, the spouse, children, and sometimes other family members (such as parents) are provided benefits in kind by the partner health insurance organization. The family left behind is officially registered with the partner insurance and receives the same benefits as other nationals. The insurance fund in the migrant-sending country receives yearly compensation calculated on real costs or on a lump-sum basis.

When family members visit the working member in the host country, their access to health care benefits is covered in case of emergency (as for other covered tourists), subject to administrative procedures, such as an exchange of the residency health insurance for visitors' insurance. The costs of such intervention are subtracted from the amounts due, which typically flow in much higher volume in the other direction-as a lump sum or for real costs.

The standard approach to establishing portable health care for mobile retirees is as follows: a retiree with a pension from Austria or Germany who establishes residency in Turkey (as a return migrant or a snowbird, with either nationality) is eligible for the Turkish health care system upon residency and registration with the Turkish social security scheme, with the same access to the health care system as any other insured person. The contribution payment and expenditure responsibility depend on whether the retiree's Austrian or German pension is his/her only pension benefit or if $s /$ he also has a Turkish pension benefit. If the latter, s/he pays (only) the Turkish contribution rate and the Turkish health insurance is fully responsible for all health care expenditures, however high his/her foreign pension(s). If the retiree has only an Austrian or German pension, s/he pays the corresponding Austrian or German contribution rate on his/her pension benefit (deducted at source) while the Turkish health insurance claims reimbursement from the relevant Austrian or German institution. This arrangement seems straightforward but has a number of nuances:

(a) The host institution/country has an incentive to avoid any responsibility for pension payment as this triggers full responsibility for health care outlays. This is the case in Turkey, where current or former Turkish nationals may cover insurance periods outside Turkey with an additional voluntary lump-sum contribution payment upon return to the social insurance pension scheme. Turkey claims that this payment is for life insurance and thus does not trigger health care responsibility, but this position is reportedly under consideration. 
(b)On the other hand, taking full responsibility for all health care outlays is inequitable if the main share of the retirement (pension) income is from abroad. Such an approach jeopardizes financial fairness between countries.

(c) Turkish expenditures for retirees by Austrian and German health care institutions are reimbursed by applying flat-rate costs (for resident expenditure), while health outlays during visits (own or covered family members) are reimbursed using actual costs. During a dispute around the flat-rate costs, it emerged that Turkey applies different family weights for Austria, France, and Germany in its calculation of reimbursement: the weight used for Austria is much higher than that for Germany but the weights of both are below that used for France.

(d)Some uncertainty reportedly remains about the right to health insurance for temporary visits by insured members in own or other countries that are party to the BSSA. This may lead to underreporting of outlays or to rejection of claims by health insurers.

\subsubsection{West corridors' BSSAs and health care portability}

Belgium and France's initial BSSAs with Morocco covered only the health care costs of traveling workers or their family members. The new France-Morocco BSSA of 2011 extends coverage to all health care contingencies outlined above and for retirees and establishes a coverage and financing process (Article 16) equivalent to that of the east corridors' BSSA: in case of eligibility to health care benefits for a retiree from one country who resides in the other country, the residence country provides the health care services while the pension benefit disbursement country covers the cost (Article 16/1); in case of eligibility to health care benefits for retirees in both BSSA countries, the residence country covers both benefit provision and financing (Article 16/3). The new Belgium-Morocco BSSA is not yet finalized. However, an administrative arrangement concluded and implemented in 2014 revises some health care-relevant articles of the old and still valid BSSA but does not yet extend health care to retirees. Compared to the east corridor, the situation is more complicated as the health care systems of Belgium, France, and Morocco all follow a two-tier scheme in which basic health care insurance is supplemented for much of the private sector labor force by contributions to a mutual health insurance. As the recent BSSA revisions are now being implemented, no information was available on how the multitier approach is addressed across these countries.

\subsection{Portability of family benefits}

The pension and health care provisions discussed so far have major family provisions that have not been discussed in detail herein, such as widows' and orphans' pensions and access to health care in home country and host country during visits for family left behind. Their access to these transfers and services depends-as a necessary condition-critically on the portability of benefits by the insured. No special issues emerged regarding pensions except for the handling of repudiation/divorces and widows' benefits in the west corridor in view of possible multiple spouses in Morocco (not Turkey) and with regard to access to health care provisions for visiting family members in the host country. 
Regulation of the portability of other family benefits, most importantly in the form of family or child allowances, is the most diverse and quite likely the most contentious contingency across the four BSSAs, for many reasons:

(a) Family benefits are not really a social security contingency or social risk but a redistributive instrument across individuals/families (from those with no children to those with children) and across an individual's life cycle (from a period without children to a period with children).

(b)They may be financed through earmarked wage contributions but are more often financed by general government revenues and thus do not establish an acquired right that needs to be protected.

(c) As a redistributive instrument, it can be argued that migrant workers should not profit to the same extent as national workers even if their children reside with them; this argument is even stronger if children reside in the home country, away from the worker.

(d)Even if the distributive argument toward migrants' children holds, the level of family benefits sent abroad may be reduced, as differences in purchasing power need to be considered.

(e) As eligibility (for example, number of children abroad) cannot be easily verified, any insurance argument for the existence of the benefit gets weaker.

(f) If the migrant-receiving country does not provide such family benefits, the reciprocity of benefits does not hold, violating a basic principle of BSSAs (for example, Turkey does not provide family benefits, but Morocco provides social insurance-related family benefits for up to six children).

Some of these considerations have led to changes in the portability rules for family allowances across the four BSSAs. In 1996, Austria unilaterally canceled the BSSA; the replacement agreement of 2000 is essentially the same but does not have a family allowance ("Familienbeihilfe"). One of the main official arguments was the misuse of the benefit, as the number of claimants' children could not be verified in Turkey. Germany faced similar issues and arguments but did not completely cancel the family benefit ("Kindergeld"). Instead, it substantially reduced the amount transferred to eligible children from Turkish workers in Turkey compared to those in Germany; it is around one-tenth but varies with the number of children. Similar discussions took place in Belgium and France but did not result in similar actions. The France-Morocco BSSA of 2011 restricts the family benefits sent abroad to cover at most four children (Article 16/6), but discussions were held about lifting the restrictions. According to the Belgium-Morocco BSSA, benefit eligibility is restricted to the pure family allowance ("prestations familiales") without special benefits or increases (Article 27/2).

\section{Evaluating the BSSAs according to criteria fulfillment}

This section presents the findings of the BSSAs' evaluation against the three criteria outlined at the beginning, covering both equity and efficiency considerations: fairness for individuals, fiscal fairness for countries, and bureaucratic effectiveness for all involved. 


\subsection{Fairness for individuals}

Section 2 outlined the conceptual framework for portability and defined fairness for individuals as no benefit disadvantage with regard to pension and health care for migrants and their dependents. Thus, one's movements between host countries or back to the home country should not lead to lower pension benefits or gaps in health coverage than if one stayed in one country.

Desk reviews of the four BSSAs as well as interviews with the responsible managers in national security institutions and ministries and representatives from migrants' organizations suggest comprehensive and well-working agreements, with very few gaps or issues on the table. ${ }^{14}$ In none of the four corridors does the BSSA create a major benefit disadvantage that affects mobility on a large scale. With the implementation of full health care benefits for mobile workers between France/Belgium and Morocco, the remaining benefit gaps, which created some but limited unfairness, are being closed: in the two-tier structure of health care insurance, mobile retirees now pay additional contributions to get local health care access.

The BSSAs in all four corridors broadly offer the expected pension portability for mobile workers, with no reported issues around the lack of take-up of benefits. A few important outstanding issues remain, particularly around the nonportability of noncontributory pension top-ups, requests for retroactive payment, and (for the west corridors) the handling of repudiation/divorces and widows' benefits.

The interviews did not suggest that pension benefits are forfeited at any sizable scale due to lack of information for eligible return migrants about their pension rights or because enabling administrative environments do not exist to apply for and get their benefits. The validity of this statement could potentially be verified by using host countries' insurance databases-at least in Austria and Germany where the migration backgrounds of the insured are known. One issue raised around benefit take-up concerned the more frequent informal labor status of migrants who moved at the beginning of the labor migration in the 1960 s and who do not have pension rights (or have them at a lower level). One corridor-specific issue concerned Germany: in the 1970s, return migrants to Turkey were allowed to cash in a lump-sum payment, an action that many beneficiaries reportedly later regretted.

Nonportability of noncontributory pension top-ups was raised for all four corridors by migrants' organizations and migrant-sending countries' administrations, and the associated mobility implications are documented in the migration literature. In essence, while nonportability can be justified on equity and insurance grounds, it risks creating a kink in potential return migrants' intertemporal budget constraints, affecting their return decision. With the top-up and other amenities, migrants are financially better off staying in the host country than returning to their home country. However, the limited return of migrants to their former home country seems to be motivated by incentives well beyond mere financial considerations: access to a more advanced health care system in the host country (albeit those in Turkey and Morocco have made significant progress); family roots established in the host country (due to family reunifications in recent decades); or estrangement over decades from family left behind.

One new contingency not covered under the investigated BSSAs (nor in any BSSA or European regulation to the author's knowledge) concerns the lack of portability of mandated long-term care insurance introduced in Germany in the 1990s. The acquired 
rights are not portable for individuals when moving abroad, and thus, the payment of $1 \%$ of salary forfeited becomes a tax. This problem, however, does not exist only for the east corridors but also affects mobility within the EU (as the author of this article can attest; see also Deutsche Welle 2013).

Another concern for individual fairness is the lack of retroactivity for payment of social security benefits. When pension applications are delayed-because of late submission, difficulties in verifying data, or any other reason-the pensioner loses access to any benefits owed up until the application is authorized. Migrants' organizations are therefore calling for a provision on retroactivity in revised BSSAs. However, the host countries' administrations prefer the alternative approach of reassembling the contributory data well before the retirement date, which may prove more effective and in line with what other countries have done or are preparing.

Last but not least, repudiation and distribution of the survivor's pension may create a fairness issue in the west corridors. Moroccan civil law (Mudawana) allows two types of dissolution of marriage: divorce and repudiation. Divorce requires spouses to go to the Tribunal to formally dissolve the marriage, which can be very costly and timeconsuming (Ouali 1992). Repudiation enables one spouse to unilaterally break the contract, which limits costs and duration. This is why men-and in a small number of cases, women-use repudiation more often than divorce. However, repudiation is not always recognized as valid in Belgian civil law for Moroccan resident in Belgium. This can lead to a risk of polygamy and can also affect both pension rates and the distribution of the survivor's pension for spouses.

Both west corridors' BSSAs foresee the splitting of the survivor's pension when polygamy exists: prorated and according to length of marriage in France, with possibility of review after the death of one spouse (France-Morocco BSSA Article 31/1) and equally and definitely in Belgium and Morocco (Belgium-Morocco BSSA Article 24/1). The provisions do not provide clear guidance in relation to spouses' nationality, however. If both are Moroccan nationals, it seems evident that Article 24 is applied since the national law permits polygamy. However, if one of the spouses is not a Moroccan national and instead is a national of a country where both repudiation and polygamy are prohibited (which is the case for Belgian nationals), Article 24 cannot be applied.

\subsection{Fiscal fairness for countries}

Evaluating fiscal fairness requires a benchmark against which to assess the impact of a BSSA and thus portability of benefits. The simple version of such a benchmark states that no participating country should have a fiscal advantage or be harmed by the agreement, but the meaning of this needs to be assessed in context. Fiscal neutrality for both countries does not mean that both do not economically benefit from the agreement compared with the situation in its absence (for example, through higher labor market formality).

\subsubsection{Financial fairness-pension regulations}

Portability of pensions means that income generated in one country is transferred to another country, not dissimilar to remittances sent from migrant-receiving to migrantsending countries, that is, a shift in purchasing power (Jousten 2012). It corresponds to the export of factor income (labor income for unfunded pensions and capital income 
for funded pensions) from the factor-using to the factor-providing country. If the pension benefit design is actuarially fair, then neither the transfer of acquired rights nor benefits in disbursement impede fiscal fairness. This may, however, be the case when the benefits contain significant distributive design components that are also transferred or in case of significant differences in life expectancy among socioeconomic groups that disadvantage lower-income groups, such as migrants, that would not be compensated. At the moment, the size of such unintended transfer components is unknown, as is the extent to which they may cancel out. The lack of a BSSA and thus portability of pension benefits clearly fiscally profits the host country-as no benefits are paid to return migrants and prior contributions were cashed-while the home country is fiscally hurt as it may have to compensate for the lack of portable old-age pensions through own and locally financed assistance benefits.

The pension structure of all countries in the investigated BSSAs follows an earningsrelated design that becomes more actuarially shaped and more fiscally fair with each reform. Major fiscal unfairness may emerge, however, through the high (and at times increasing) level of government transfers to cover the increasing imbalance between pension contributions (from employee and employer) and pension outlays. In all host countries, a significant share of pension expenditure is paid by budgetary transfers (up to one third).

A significant and so far little discussed source of fiscal unfairness may come from outside the pension system, in the treatment of contributions, interest earned, and benefits disbursed in the tax system. Because tax deductions have been granted to pensions during the accumulation phase (for example, through nontaxation of contributions and interest earned) that would be recovered through the taxation of benefits when disbursed, fiscal neutrality may be hurt but not under all circumstances. Nontaxation of returns on retirement savings may not be a privilege but merely the taxation principle under a consumption-type tax treatment. On the other hand, beneficiaries may also be taxed twice: during the accumulation phase in the working country when contributions are non-tax-deductible and then again at retirement if pensions are fully taxed in the residency country of retirement. Yet, the taxes levied in the new recipient country may simply pay for the public goods and services provided. The tax transfer mechanism may include age-related transfers when beneficiaries are young (for example, child allowances and housing subsidies) that are recovered when they are older, including when drawing a pension. Then, the pension-sending country would lose and the pension-receiving country would gain.

As Table 9 highlighted, the tax treatment of portable pension benefits in the home country varies tremendously across the four corridors. This heterogeneous tax treatment is bound to create fiscal unfairness among countries even without spelling out in which direction (this is done in the individual corridor studies). The amount of tax expenditure in the tax source (and pension host) country and how the taxation rights of pensions in disbursement should best be arranged between source and residency country are empirically unknown and conceptually and operationally unclear. This area of international coordination of financial flows has until now been left largely to the legal profession and to its treatment in DTTs-the BSSA equivalent for taxation issues. The international taxation of portable pensions and how best to establish individual and fiscal fairness with minimal bureaucratic hassles is still unknown territory. Yet, to 
Table 9 Taxation of pension benefits by origin of payment and residency of recipient

\begin{tabular}{|c|c|c|c|c|}
\hline & German pension & Austrian pension & Belgium pension & French pension \\
\hline $\begin{array}{l}\text { Taxation in } \\
\text { source country }\end{array}$ & Source taxation & No & Source taxation & No \\
\hline $\begin{array}{l}\text { Taxation in } \\
\text { residence } \\
\text { country (Turkey } \\
\text { or Morocco) }\end{array}$ & $\begin{array}{l}\text { No_-all pensions are } \\
\text { tax free in Turkey (not } \\
\text { considered taxable } \\
\text { income) }\end{array}$ & $\begin{array}{l}\text { No_all pensions are } \\
\text { tax free in Turkey (not } \\
\text { considered taxable } \\
\text { income) }\end{array}$ & $\begin{array}{l}\text { No-exempt from } \\
\text { taxation through } \\
\text { DTT 1972, Article } \\
18\end{array}$ & $\begin{array}{l}\text { Yes—-special } \\
\text { regimes, with tax } \\
\text { allowance between } \\
40 \text { and } 80 \%^{a}\end{array}$ \\
\hline
\end{tabular}

Source: Holzmann et al. 2016a, 2016b, 2016c, 2016d

aLe Monde 2013

clarify the concepts and get a better understanding of the flows involved, some first research steps have been launched. ${ }^{15}$

\subsubsection{Financial fairness - health care regulations}

Public health care systems are typically designed to give everyone access to a comprehensive set of services. Contributions are typically flat or a fixed share of income, while expenditures rise strongly with age. When developing countries send more young net contributors abroad and receive more elderly net beneficiaries, their public health systems are burdened. On the other hand, migrant women who give birth to children in the host country burden this health care system more during this episode relative to the revenues they contribute. Worldwide, no arrangement is in place to share the savings components of health care provisions of a migrant who contributed to the public health institutions of various countries (Werding and McLennan 2015; Holzmann and Koettl 2015).

Under the BSSAs investigated, two key elements may negatively affect the fiscal position of the country that provides health care benefits for mobile retirees:

(a) The full expenditure responsibility of the residence country for all health care outlays if the retiree receives a pension from this country, however small compared to other (pension) income from abroad. This creates a health cost disadvantage if return migrants have only a small home and large host pension benefit, and health care contributions are only levied on the home pension, as currently seems to be the case in the corridors; if contributions are levied on all pension income received, contribution revenues may still not be cost covering. For the assessment of the latter, age-related (not average) cost coverage should matter, which is not the current practice.

(b) The "across-the-board" compensation from the host country that also pays a retiree's only pension. While three methods are used internationally for health cost recovery, Turkey currently uses the across-the-board method for retirees. The alternatives are "actual values" (that is, real costs incurred by the insured) and "average values" calculated on actual outlays over four quarters of the year. Actual values are used for emergency cost recovery for temporary eligible visitors. Across-the-board cost recovery is certainly administratively less burdensome (albeit private insurers use actual values) but may lead to major underpayment for older health care beneficiaries.

Viewed in this context, the current approach of portable health care may be seen as fiscally unfair to Turkey, but this assumes that cost recovery is based on across-the- 
board values related to actual outlays. This may not be the case. During quality checks, fluctuations in the average health care costs presented by Turkey that could not be explained by real developments attracted the attention of Austrian authorities. In comparing Turkey's calculation bases with those of Germany and France, Turkey was found to be using different family weights (recall Section 4.4.1). Following negotiations, the same family factor used for Germany is now also used for Austria (Wieninger 2013).

For Turkey, the main concern related to health care benefits is due to new levies imposed on pension income by the EU. The EU changed its internal regulations in 2002 and introduced supplementary premiums from pensions for health services. Turkey has argued that this practice is at odds with the provisions in the BSSA and unfairly affects residents of states that are not members of the EU's common social security system. ${ }^{16}$

In summary, it is not clear whether fiscal neutrality of portable health care is achieved in the current BSSAs and existing legal environments. This ambiguity may be due less to the lack of a conceptual framework (Holzmann and Koettl 2015; Werding and McLennan 2015) and more to a traditional and disputed implementation as well as differences in how countries themselves finance their health care provisions.

\subsection{Bureaucratic effectiveness}

Critical elements required to keep the bureaucratic burden low for migrants and social security institutions include appropriate information for potential beneficiaries, timely records on insurance periods, and electronic communications and file exchange between institutions. In all four investigated BSSAs, room for improvement exists in all three elements.

\subsubsection{Available information sources for migrants}

Due to the age structure of migrants, their pensions represent a comparatively recent issue, and not all eligible persons may be aware of the BSSAs' provisions. Furthermore, migrant retirees from emerging economies often have a low educational level and are not used to contact with the social security administration. In addition, they face language barriers and have often had discriminatory experiences with the administration. These factors can contribute to retirees' difficulties in understanding their benefits. Advisory services provided by both home and host countries can play a part in overcoming these barriers.

Overall, advisory services provided by Austria and Germany are generally viewed favorably by migrants. In both Austria and Germany, three key actors offer information and support: (a) social security institutions, which reach out to (Turkish) migrants through a diverse set of interventions, including regional information and support sessions; (b) the social attaché of the Turkish embassy, which advises Turkish citizens on pension and health insurance issues; and (c) migrants' organizations, which offer information and facilitate links between migrants and the social security administration (for details, see Holzmann et al. 2016a, 2016b).

Three types of interventions are currently used in Belgium, France, and Morocco to inform potential beneficiaries of the contents and coverage of the BSSA: institutional contact centers, information sessions, and direct communication with beneficiaries. It is relatively easy for pensioners to liaise with contact center staff. However, information sessions organized by Office National des Pensions in the Moroccan cities with the 
largest population of returnees often struggle to reach a large number of potential beneficiaries. Privacy concerns can exacerbate this. For example, past requests by Moroccan institutions to Belgium to share potential beneficiaries' contact details available in the Belgian administrative database have been rejected by Belgium for privacy reasons. In the future, both countries will need to pursue avenues to ensure migrant retirees' access to social security rights without breaches of privacy.

While information provision by the host countries seems to work well overall, local advisory services provided by public institutions in both Morocco and Turkey are viewed by migrants' organizations as inadequate, with a lot of room for improvement. The most common complaint is that administrative staff are not fully informed on the BSSAs' contents and administrative processes and thus they cannot provide adequate information to clients. No information is currently available about information material, visitor statistics, advising sessions, and so on.

\subsubsection{Delays in the application process}

It takes longer to process cross-national pension applications than national pensions. Frequent delays occur during the confirmation of the extent of insurance periods in Morocco and Turkey, as local institutions must generate individual insurance data from documents provided in paper form by regional offices. The list of insurance periods is collected only at the time of a pension application, and account clearances with yearly entitlement announcements do not exist. Thus, for example, the pension application for the Austrian or German part is processed very quickly as the domestic insurance file is essentially ready at the time of application, but in Turkey, the process may take many months (for details see Holzmann et al. 2016a, 2016b). Similar experiences are also reported for the west corridors.

Difficult cases of pension application or access to health care are brought to the attention of periodic bilateral meetings, but the involved parties attempt to handle such cases beforehand using informal electronic interactions and other communications.

\subsubsection{Electronic data exchange and modernization}

The EU corridor countries generally intend to subject older agreements to a collective revision, as both the EU and national regulations have been further developed (for example, related to data protection regulations). Electronic data exchange would improve both the fight against fraud (for example, disclosure of a double submission of bills) and cooperation between institutions (for example, ascertainment of the actual primary residence of a pensioner).

The implementation of ITC-based exchanges between EU and neighboring countries can be inspired by the dedicated ITC system at the core of the multilateral agreement MERCOSUR between Argentina, Brazil, Paraguay, and Uruguay (CIDI Consejo Interamericana para el Desarrollo Integral 2015). This innovative ITC system is reliable and trusted (generating a trace for each exchange in a trusted institution: Organizacion Iberoamericana de Seguridad Social; is separate from that of each national participating social institution but can be easily linked to; has strong data protection and privacy features; enables effective and efficient data exchange that reduces time requirements between countries from months to days; and is easy to install and use (as it is web-based). The ongoing development includes an automatic payment management to avoid bank fees; allows for direct transfer in local currency (eliminating 
the need to transfer using US dollar transactions); and offers a compensation system to reduce transfers (Ruggia-Frick 2011, 2015).

\section{Conclusions}

The overall conclusions from the four investigated corridors are relatively encouraging. The four investigated BSSAs seem to be broadly working, with only a few areas of contention and recognized areas for improvement. With some exceptions, this assessment essentially holds for all three criteria used to evaluate the BSSAs: fairness for individuals, fiscal fairness for countries, and bureaucratic effectiveness.

Fairness for individuals: BSSAs do not create a major benefit disadvantage that affects mobility on a large scale in any of the four corridors. Implementation of full health care benefits for mobile workers between France/Belgium and Morocco will close a remaining relevant benefit gap. The BSSAs offer the expected pension portability for mobile workers, with no major issues around the lack of benefit take-up. A few important outstanding issues remain, particularly the nonportability of noncontributory pension top-ups, requests for retroactive payment, and (for the West corridor) the handling of repudiation/divorces and widows' benefits. Family allowances remain an issue for discussion, and different outcomes across the corridors may prevail. Fiscal fairness for countries: The pension systems' evaluation yields a mixed picture. For the four BSSAs considered, their increasingly actuarial pension benefit structure helps in the pursuit of fairness; high and increasing levels of budgetary transfers to keep pension systems afloat have a counter effect. For health care systems, it is unclear whether and to what extent fiscal fairness is or can be achieved under the current responsibility and reimbursement structure and how important the problem is. Bureaucratic effectiveness: Stakeholders gave EU host countries' institutions high marks for their provision of benefit-related information and services but had a less favorable assessment for their home countries. A concern for many applicants is the delay in processing; the advantages of advanced electronic file preparation in some but not all EU countries are attenuated by the paper-based information collection systems in Morocco and Turkey; the situation is further aggravated by verification issues for names and birth dates. Electronic file exchange systems across BSSAs are envisaged and may soon take place in some corridors.

While the four corridor studies offer a lot of useful information and insights, they are not rich enough to draw firm conclusions to drive major policy changes for BSSAs. However, their comparison and individual evaluations in relation to the three criteria do allow for some suggestions about next steps, including thoughts about policy developments, and invite some reflections, such as:

Does portability or its absence matter? If so, is it for labor mobility or social risk management; for what phase of labor mobility_departing, staying, or returning_and for what part of risk management-pension, health, and so on? The findings in the corridor studies are consistent with sparse empirical evidence that departure consideration may be little influenced by the presence or absence of portability (even if the reviewed BSSAs from the 1960s were considered an important competitive 
element); for example, no BSSAs exist between Mexico and the USA or between Asian and Gulf Cooperation Council countries, although these are the largest migration corridors globally. This suggests implications for the risk management of migrants (forcing own provisioning) and home countries (offering special arrangements such as health care by Mexico and a range of support programs by the Philippines). Portability arrangements seem to have some but limited effect on return migration while some specificity of pension and health care provisions may make many migrants stay on; for pensions, it is top-ups that seem to matter, while for health care, it is access to high-quality care if needed. It would be interesting and relevant to experiment with limited portability of top-ups and/or selective access to health care to former host countries for return migrants (including visas) to explore the mobility effects.

What are the conclusions, if any, for low-income countries/minimum requirements? For a BSSA to be worthwhile, a developing country needs to have a sizable migration corridor that offers its migrants access to receiving countries' social security systems (not the case in the Gulf Cooperation Council countries, Malaysia, Singapore, and so on). However, the developing country should also have a (perhaps small) functioning social security system or at least one or two well-operating schemes. Similarity between the host and home country schemes also helps, or the host country will have limited interest in engaging in a BSSA and no credibility with and interest by its own migrants to participate at home and abroad. Furthermore, operation of the relevant scheme should be computerized (ideally with a unique personal identification number), have birth and death certificates, and have an institutional setup that takes care of its migrants for departure, during their stay, and upon return.

What should lower-income countries pursue: a narrow or an ambitious approach to BSSAs? A narrow approach with a focus on few benefits, particularly on pensions (oldage, disability, and survivor's), work injury, and health care for family members left behind and visiting has higher chances of early success. Renegotiating the BSSA for broader benefits such as family allowance and health care in retirement when the migration corridor intensifies and domestic equivalents are created is possible but requires a more lengthy process. Striving from the very beginning for a comprehensive BSSA and benefit coverage as within the EU may not be very promising and would need to build on a very strong migration corridor. Current signals from the EU indicate a reluctance to include health care in future third country agreements.

Are private sector provisions easier to make portable? Not necessarily, and in any case, this would only be relevant for long-term contingencies-retirement and health care. Private saving offers a first defense against many financial risks in life, and money should be easy to carry when moving from country to country. However, finding reliable financial institutions at home and abroad to park the money remains a challenge. In addition, private sector pension arrangements often profit from tax privileges during the accumulation phase that countries increasingly take back when leaving the country and the exit tax may be sizable. Private health care insurance is not easily portable between countries (or even within countries) so that sizable savings elements get lost when moving. Even within the EU, private provisions (for pension and health care) are much less portable than public and mandated ones. This has given rise to panEuropean or international private programs in health and preparation of a panEuropean fund for supplementary pension benefits. 
The recommendations for the next steps to better understand BSSAs to offer relevant policy proposals for redesign and implementation focus on the research agenda, as important data, relevant concepts, and empirical evidence are still missing. Main research elements include the following:

(a) The information base should be broadened with further south-north corridor studies for other regions as well as studies for north-north corridors (inside and outside the EU) and south-south corridors within and outside multilateral agreements.

(b)Future corridor studies should spend more resources and time on development of a full result framework and the collection of micro- and macroeconomic data from social security institutions and beyond. This would allow for rigorous quantitative evaluation of BSSAs according to the proposed and other criteria.

(c) Independent of corridor studies, countries should be encouraged to provide much more information about portability-related flows and transactions between countries and to offer administrative data (as anonymized files) for research purposes.

(d)Future evaluations should profit from progress in the conceptual and empirical deepening of fiscal fairness, particularly for pension and health care programs.

(e) Such conceptual extensions would profit from in-depth empirical analysis of the current health care corridors and their financing and reimbursement mechanisms.

(f) A better analytical foundation is needed to determine which benefits should get priority in BSSAs and which should be dropped. While comprehensiveness may be laudable, it comes at a price, namely a BSSA's delayed finalization or implementation.

(g)Regardless of their overall design, future BSSAs will profit enormously from having a monitoring and evaluation framework built in from the very beginning.

It is strongly hoped that this project will motivate further corridor studies in different regional and economic settings and that its research methodology will be used to test the findings' resonance and explore their broader applicability or rejection.

\section{Endnotes}

${ }^{1}$ For some corridor countries, better cross-sectional data are available but cannot be easily transformed into longitudinal data and compared with similar data across countries. For some of the German data on pensions to Germans and foreigners, see Himmelreicher and Keck (2015).

${ }^{2}$ For the individual corridor studies, see Holzmann et al. 2016a, 2016b, 2016c, $2016 \mathrm{~d}$. For a comparison across the east corridors, see Fuchs and Pacaci-Elitok 2014; for the west corridors, see Legros et al. 2014 and Wels et al. 2015 (in French). For an elaboration of broader principles and further country experiences with portability, see the papers in a special volume of CESifo Economic Studies 2015 and the overview paper by Holzmann and Werding 2015.

${ }^{3}$ Portability issues continue existing also within countries, most importantly between the public and private sector and between states and regions in federal countries such as China. These are ignored in this paper.

${ }^{4}$ Some authors claim that in a second-best world, imperfect portability could be welfare-improving in the presence of several market failures (see, for example, Becker 
1964; Lazear 1979; and Fabel 1994). While these arguments may have some validity for national labor markets, it is doubtful that such a human Tobin tax through imperfect portability is relevant in cases of cross-border mobility, as the other involved costs will remain high.

${ }^{5}$ For some historic and legal background on BSSAs, see Strban (2009); for a review of issues of BSSAs with non-members within the EU context, see Spiegel (2010); for a legal analysis of social security coordination with southern and eastern Europe, see ILO (International Labour Organization) (2012); for a review of literature, see Taha et al. (2015). For the texts of the bilateral social security agreements worldwide, see the ILO NATLEX database: www.ilo.org/dyn/natlex/natlex4.search?p_lang=en.

${ }^{6}$ Algeria, Egypt, Israel, Jordan, Lebanon, Morocco, Syria, Tunisia, Turkey, and the Palestinian Authorities.

${ }^{7}$ For an analysis of EU member states' BSSAs with third countries, including comparison tables of the contents of these BSSAs, see Spiegel (2010).

${ }^{8} \mathrm{~A}$ recent analysis by the Organization of American States on the regional functioning of bilateral and multilateral social security agreements is a useful step (CIDI Consejo Interamericana para el Desarrollo Integral 2015). The study offers an informative description of the history and status of the agreements; yet, the analysis assesses only the legal content of the agreements without any benchmark and outcomes.

${ }^{9}$ See Gsir et al. (2015) for a recent corridor report on Belgium and the immigrants from Morocco and Turkey.

${ }^{10}$ For the east corridor, see Fuchs and Pacaci-Elitok (2014). For the west corridor, see Legros et al. (2014) and Wels et al. 2015 (in French).

${ }^{11}$ See Holzmann et al. (2016a, 2016b) for the Austria-Turkey and Germany-Turkey corridors; Holzmann et al. (2016c) for the Belgium-Morocco corridor; and Holzmann et al. (2016d) for the French-Morocco corridor. All corridor papers can be found at the World Bank website www.worldbank.org/en/topic/socialprotectionlabor.

${ }^{12}$ This abstracts from the moving 500-year military frontier between the Hapsburg Empire and the Turkish Empire between the fall of Constantinople (1453) and the nineteenth century and the population movement involved.

${ }^{13}$ The data by social security institution offer information on how many pensions are paid abroad but typically do not allow individuals to be distinguished by nationality or country of origin. As a result, a pension paid to Morocco can be paid to a Moroccan with Moroccan nationality, a naturalized Moroccan, or a French snowbird. Similarly, it is unknown how many pensions paid in EU countries are to naturalized migrants and how many to foreign passport holders. However, information about migration streams between countries (which may include migrants from both sending and receiving countries) signals limited return migration shortly before or after retirement.

${ }^{14}$ In the individual corridor studies, references to these interviews are made and included in the list of references if permission was given by the interviewees. The minutes of all interviews are available for further research purposes but for confidentiality reasons cannot be made public. The author would again like to thank all those who made themselves available for interviews; they contributed significantly to the understanding of BSSAs and their intricacies. All remaining errors are the author's own.

${ }^{15}$ To explore and develop the under-researched topic of the taxation of pensions, including the issue of the taxation of portable benefits, the Center for Economic Studies \& 
Ifo Institute CESifo (Munich) and the Centre of Excellence In Population Ageing Research CEAPR (Sydney) initiated a project with workshops in Sydney (held in November 2014) and Munich (held in September 2015). For details of programs and output, see http://www.cesifo-group.de/ifoHome/events/Archive/conferences/ 2015/09/2015-09-03-tag15-Holzmann.html. The revised papers are published as CESifo Working Papers at https://www.cesifo-group.de/ifoHome/publications/working-papers/CESifoWP.html, including the policy issue paper on the taxation of internationally portable pensions; see Genser and Holzmann (2016). A book publication is under preparation.

${ }^{16}$ The new regulation also applies to Austrian residents in receipt of an Austrian public pension and health insurance who also receive a public pension from an EU member state. A health insurance contribution is levied on the pension from abroad as health care benefits are provided locally.

\footnotetext{
Acknowledgements

I would like to thank the anonymous referee and the editor for the useful remarks. Responsible editor: Martin Kahanec

The paper profited from suggestions by the participants of the June 2015 consultation seminar at the Marseille Center for Mediterrean Integration, a seminar presentation at Istituto Nazionale della Previdenza Sociale INPS headquarters in Rome in April 2016, comments by the co-authors of the corridor studies, and written comments by Jason Gagnon (OECD), Aline Coudouel, Cem Mete, and Robert Palacios (all World Bank). The author takes responsibility for all remaining errors.

Robert Holzmann is a Fellow of the Austrian Academy of Sciences (Vienna); Honorary Professor, University of Malaya (Kuala Lumpur); Honorary Chair, Centre of Excellence in Population Ageing Research, University of New South Wales (Sydney); and Research Fellow of IZA (Bonn) and CESifo (Munich). He was an academic in Austria and Germany and has held various positions at the International Monetary Fund, OECD, and the World Bank.
}

\section{Competing interests}

The IZA Journal of European Labor Studies is committed to the IZA Guiding Principles of Research Integrity. The author declares that he has observed these principles.

Received: 7 June 2016 Accepted: 6 September 2016

Published online: 13 October 2016

\section{References}

Avato J, Koettl J, Sabates-Wheeler R (2010) Social security regimes, global estimates, and good practices: the status of social protection for international migrants. World Development 38:455-66

Becker G (1964) Human capital: a theoretical and empirical analysis. Colombia University Press, New Work

CIDI (Consejo Interamericana para el Desarrollo Integral) (2015) Análisis de Convenios Bilaterales y Multilaterales de Seguridad Social en Materia de Pensiones. Segunda Reunion de los Grupos de Trabajo de la XVIII Conferencia Interamericana de Ministros de Trabajo (CIMT), Cartagena, Colombia, pp 28-30

Deutsche W (2013) Germany's pension system tricky for foreigners., Top Stories, August 5, 2013. http://www.dw.com/ en/germanys-pension-system-tricky-for-foreigners/a-16996930. Accessed 16 Sep 2016

Eurostat (2015) Immigration in the EU., http://ec.europa.eu/dgs/home-affairs/e-library/docs/infographics/immigration/ migration-in-eu-infographic_en.pdf. Accessed 16 Sep 2016

Fabel O (1994) The economics of pensions and variable retirement schemes. Wiley, Chichester

Fuchs M, Pacaci-Elitok S (2014) Portability of pensions and health care for pensioners - joint summary document east corridor (Austria, Germany vs. Turkey). Commissioned by the World Bank - Study, 5 M Migration MGMT Initiative Phase I (P127358). European Centre for Social Welfare Policy and Research, Vienna

Furat Oemer F (2011) The application of long-term pension provisions on bilateral agreements. SGK, PPT presentation in Zagreb, Croatia

Genser B, Holzmann R (2016) The taxation of internationally portable pensions: fiscal issues and policy options. CESifo, Munich, CESifo Working Paper No. 5702, January

Gsir S, Mandin J, Mescoli E (2015) Corridor report on Belgium: the case of Moroccan and Turkish immigrants. Turkish Immigrants, INTERACT RR 2015/03, Robert Schuman Centre for Advanced Studies, San Domenico di Fiesole (FI): European University Institute

Himmelreicher R, Keck W (2015) Transnational ageing as reflected in pension insurance. In: Vinzent H, Cornelia S (eds) Transnational ageing — current insights and future challenges, 5th edn. Routledge, New York and London, pp 107-124

Holzmann R (2015) Taxing pensions of an internationally mobile labor force: portability issues and taxation option. In: CEPAR Working Paper 2105/27. University of New South Wales, Sydney

Holzmann R, Koettl J (2015) Stability of pension, health, and other social benefits: facts, concepts, and issues. CESifo Economic Studies 61(2):377-415. doi:10.1093/cesifo/ift017, Munich: CESifo 
Holzmann R, Pouget Y (2012) Social protection for temporary migrant workers: what programs serve them best? In: Omelaniuk I (ed) Global perspectives on migrant and development: GFMD Puerto Vallerta and beyond. A publication by the global forum on migration and development. Springer, New York-Heidelberg, pp 61-85

Holzmann R, Werding M (2015) Portability of social benefits: research on a critical topic in globalization. CESifo Economic Studies 61(2):1-11. doi:10.1093/cesifo/ifv009, Munich: CESifo

Holzmann R, Koettl J, Chernetsky T (2005) Portability regimes of pension and health care benefits for international migrants: an analysis of issues and good practices, Social Protection Discussion Paper No. 0519. (also available in French). World Bank, Washington, DC

Holzmann R, Wels J, Dale P (2016a) Assessing benefit portability for international migrant workers: lessons learned from a review of the Morocco-Belgium bilateral social security agreement. In: Social Protection \& Labor Global Practice. The World Bank, Washington, DC

Holzmann R, Legros F, Dale P (2016b) Assessing benefit portability for international migrant workers: lessons learned from a review of the Morocco-France bilateral social security agreement. In: Social Protection \& Labor Global Practice. The World Bank, Washington, DC

Holzmann R, Fuchs M, Pacaci-Elitok S, Dale P (2016c) Assessing benefit portability for international migrant workers: lessons learned from a review of the Turkey-Austria bilateral social security agreement. In: Social Protection \& Labor Global Practice. The World Bank, Washington, DC

Holzmann R, Fuchs M, Pacaci-Elitok S, Dale P (2016d) Assessing benefit portability for international migrant workers: lessons learned from a review of the Turkey-Germany bilateral social security agreement. In: Social Protection \& Labor Global Practice. The World Bank, Washington, DC

ILO (International Labour Organization) (2012) Social security coordination for non-EU countries in South and Eastern Europe: a legal analysis. ILO, Geneva

INSSE recensement (2008) http://www.insee.fr/. Accessed 16 Sep 2016

INSSE recensement (2010) http://www.insee.fr/. Accessed 16 Sep 2016

Jousten A (2012) The retirement of the migrant labor force: pension portability and beyond, CESifo Working Paper Series No. 3995. CESifo, Munich

Lazear E (1979) Why is there mandatory retirement?". Journal of Political Economy 87:1261-1284

Manning P (2013) Migration in world history, 2nd edn. Routledge, New York

Maunu J (2014) Select digital resources for migration in world history, World History Connected., October. Available at: http://worldhistoryconnected.press.illinois.edu/11.3/maunu.html. Accessed 16 Sep 2016

Monde Le (2013) Les "paradis fiscaux". des retraités français 24(05):2013

Ouali N (1992) La convention belgo-marocaine de coopération judiciaire en matière civile. L'Année Sociale., pp 267275, Retrieved from http://difusion.academiewb.be/vufind/Record/ULB-DIPOT:oai:dipot.ulb.ac.be:2013/63565/Details. Accessed 16 Sep 2016

Poulain M, Perrin N (2008) Measuring international migration: a challenge for demographers. In: Surkyn J et al (eds) Demographic challenges for the 21st century - a state of art in demography. VUB Press, Liber Amicorum Ron Lesthaeghe Brussels, pp 143-173

Ruggia-Frick R (2011) MERCOSUR social security agreement: ICT implementation. ISSA, Geneva

Ruggia-Frick R (2015) ISSA guidelines on information and communication technology: overview. ISSA, Geneva

Spiegel B (2010) Analysis of member state's bilateral agreements on social security with third countries. Report ordered by the European Commission, Employment, Social Affairs, and Equal Opportunity DG, Brussels

Strban G (2009) The existing bi-and multilateral social security instruments binding EU States and non-EU states. In: Pieters D, Schoukens P (eds) The social security co-ordination between the EU and Non-EU countries. Intersentia, Antwerpen - Oxford, pp 85-113

Taha N, Siegmann KA, Messkoup M (2015) How portable is social security for migrant workers? A review of literature. International Social Security Review 68(1):95-118

United Nations - Department of Economic and Social Affairs (2015) Trends in international migration, 2015., Population Facts No. 2015/4, December http://www.un.org/en/development/desa/population/migration/publications/ populationfacts/docs/MigrationPopFacts20154.pdf. (Accessed 16 Sep 2016)

Wels, Jacques, Nawal Bensaid, and Florence Legros. 2015. «La transportabilité des prestations de sécurité sociale en matière de retraite, de soins de santé et de minimas sociaux, revue « Hommes et Migrations » - « Les migrants vieillissants », 1309, mars.

Werding M, McLennan S (2015) International portability of health-cost coverage: mobility, insurance, and redistribution. CESifo Economic Studies 61(2):484-519. doi:10.1093/cesifo/ifu022, First published online May 27, 2015

Wieninger P (2013) Head of Department International and European Social Insurance Affairs, Umbrella Organisation of the Austrian Social Insurance Institutions., Austrian Liaison Agency health insurance, accident insurance, pension insurance. Personal communication (September 3) 